\title{
TephraKam: geochemical database of glass compositions in tephra and welded tuffs from the Kamchatka volcanic arc (northwestern Pacific)
}

\author{
Maxim V. Portnyagin ${ }^{1,2}$, Vera V. Ponomareva ${ }^{3}$, Egor A. Zelenin ${ }^{4}$, Lilia I. Bazanova ${ }^{3}$, Maria M. Pevzner ${ }^{4}$, \\ Anastasia A. Plechova ${ }^{2}$, Aleksei N. Rogozin ${ }^{3}$, and Dieter Garbe-Schönberg ${ }^{5}$ \\ ${ }^{1}$ GEOMAR Helmholtz Centre for Ocean Research Kiel, 24148 Kiel, Germany \\ ${ }^{2}$ V.I.Vernadsky Institute for Geochemistry and Analytical Chemistry, Moscow, 119991, Russia \\ ${ }^{3}$ Institute of Volcanology and Seismology, Petropavlovsk-Kamchatsky, 683006, Russia \\ ${ }^{4}$ Geological Institute, Moscow, 119017, Russia \\ ${ }^{5}$ Institute of Geosciences, Kiel University, 24118 Kiel, Germany
}

Correspondence: Maxim V. Portnyagin (mportnyagin@geomar.de)

Received: 21 October 2019 - Discussion started: 30 October 2019

Revised: 30 January 2020 - Accepted: 30 January 2020 - Published: 27 February 2020

\begin{abstract}
Tephra layers produced by volcanic eruptions are widely used for correlation and dating of various deposits and landforms, for synchronization of disparate paleoenvironmental archives, and for reconstruction of magma origin. Here we present our original database TephraKam, which includes chemical compositions of volcanic glass in tephra and welded tuffs from the Kamchatka volcanic arc. The database contains 7049 single-shard major element analyses obtained by electron microprobe and 738 trace element analyses obtained by laser ablation inductively coupled plasma mass spectrometry on 487 samples collected in close proximity to their volcanic sources in all volcanic zones in Kamchatka. The samples characterize about 300 explosive eruptions, which occurred in Kamchatka from the Miocene up to recent times. Precise or estimated ages for all samples are based on published ${ }^{39} \mathrm{Ar} /{ }^{40} \mathrm{Ar}$ dates of rocks and ${ }^{14} \mathrm{C}$ dates of host sediments, statistical age modeling and geologic relationships with dated units. All data in TephraKam are supported by information about source volcanoes and analytical details. Using the data, we present an overview of geochemical variations in Kamchatka volcanic glasses and discuss applications of these data for precise identification of tephra layers, their source volcanoes, and temporal and spatial geochemical variations in pyroclastic rocks in Kamchatka. The data files described in this paper are available on ResearchGate at https://doi.org/10.13140/RG.2.2.23627.13606 (Portnyagin et al., 2019).
\end{abstract}

1

Tephra layers are widely used for correlation and dating of various deposits and landforms, for the synchronization of disparate paleoenvironmental archives, and for reconstruction of magma origin and temporal evolution. These applications are in high demand in paleoclimatology, paleoseismology, archaeology, and other Quaternary science disciplines (e.g., Lowe, 2011), as well as in petrology and geochemistry (e.g., Cashman and Edmonds, 2019; Ponomareva et al., 2015a; Straub et al., 2015). Tephra is composed of miner- als, volcanic glass (melt rapidly quenched upon eruption), and rock fragments in different proportions. A major modern approach for correlation of tephra layers between different locations is using major and trace element composition of volcanic glass (e.g., Cashman and Edmonds, 2019; Lowe, 2011; Ponomareva et al., 2015a). The composition of volcanic glasses has been shown to vary significantly on spatial scales ranging from volcanic region to a single volcano, reflecting a large variability of thermodynamic conditions of magma storage and fractionation and the composition of crustal and mantle sources of magmas (e.g., Bachmann and 
Bergantz, 2008; Cashman and Edmonds, 2019; Frost et al., 2001; Pearce, 1996; Pearce et al., 1984; Schattel et al., 2014).

Tephra often dominates the erupted products in terms of volume, eruption frequency, and variety of compositions, some of which may never occur in lava. It is particularly true for highly explosive volcanic arcs where the vast majority of the magma is erupted as tephra (e.g., Kutterolf et al., 2008). Therefore, tephra studies have a large, still only partly explored, potential to trace temporal and spatial variations in magma compositions in volcanic arcs (e.g., Clift et al., 2005; Kimura et al., 2015; Straub et al., 2004, 2015).

The Kamchatka Peninsula (Fig. 1) hosts more than 30 recently active large volcanic centers and a few hundred monogenetic vents, comprising the northwestern segment of the Pacific Ring of Fire. Kamchatka volcanism is highly explosive. According to some estimates, Kamchatka has the largest number of Quaternary calderas per unit of arc length in the world (Hughes and Mahood, 2008). Kamchatka tephra layers provide chronological control for deposits and events over large areas, both in Kamchatka and farther afield, up to Greenland and North America, which is critical for many studies (e.g., Cook et al., 2018; Hulse et al., 2011; Kozhurin et al., 2014; Mackay et al., 2016; Pendea et al., 2016; Pinegina et al., 2013, 2014, 2012; Plunkett et al., 2015; van der Bilt et al., 2017). However, geochemical characterization of Kamchatka volcanic glasses is still in a developing phase. In the Kamchatka volcanic arc, the Holocene tephrochronological framework (until recently) has been based mainly on direct tracing of tephra layers, bulk composition of tephra, and bracketing radiocarbon dates (e.g., Bazanova et al., 2005; Braitseva et al., 1998, 1996, 1995, 1997; Pevzner, 2010; Pevzner et al., 1998, 2006). Significant progress towards creating geochemical database of Kamchatka tephras has been achieved in the past 10 years (Dirksen et al., 2011; Kyle et al., 2011; Plunkett et al., 2015; Ponomareva et al., 2013a, b, 2017, 2015b). However, the published geochemical data are mostly restricted to the Holocene and do not include data on trace element composition of volcanic glasses.

In this paper, we present TephraKam - our original, internally consistent and, so far, most complete database of single-shard glass composition from tephras and welded tuffs of Kamchatka volcanoes, covering the period from the Miocene until the present (Portnyagin et al., 2019). The data have been collected during the past 10 years and include major element compositions obtained by electron microprobe and trace element compositions of representative samples by laser ablation inductively coupled plasma mass spectrometry (LA-ICP-MS). Ages based on published radiocarbon and ${ }^{39} \mathrm{Ar} /{ }^{40} \mathrm{Ar}$ dates, as well as on the age models and stratigraphy, are provided for all samples. Using these data, we present an overview of geochemical variations in Kamchatka volcanic glasses and suggest some key geochemical parameters and diagrams, which permit precise identification of tephra layers and their sources and assessment of regional geochemical variations in Kamchatka. The re-

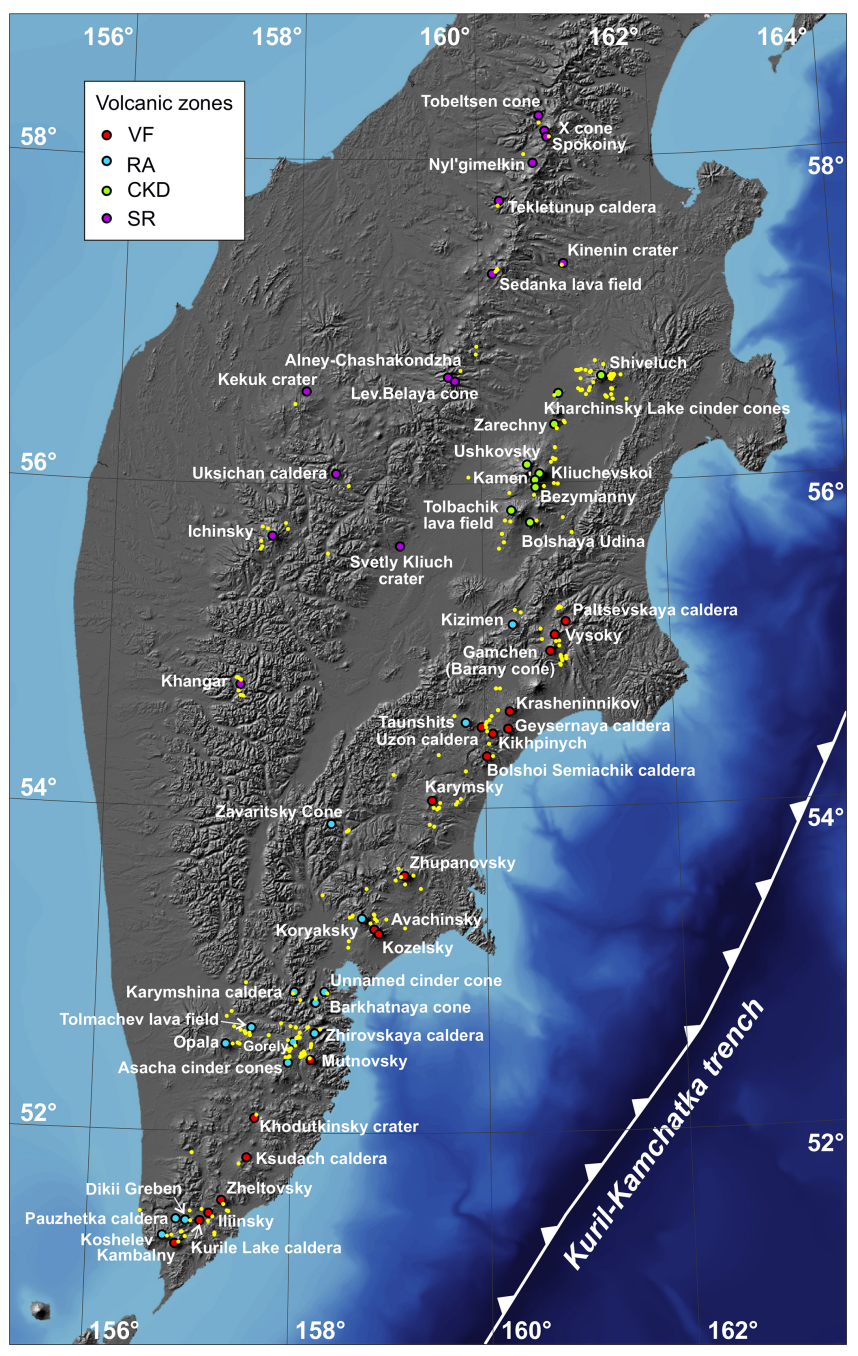

Figure 1. Volcanoes and samples presented in TephraKam. Large red circles with labels are volcanic centers, and yellow circles are sample locations. Note that Kamchatka hosts more presently inactive volcanic centers than shown on the map, but tephra samples from these extinct volcanoes were not available for this study. The background image was drawn by the authors using public-domain datasets: SRTM for landmass (Farr et al., 2007) and GEBCO for ocean floor (Smith and Sandwell, 1997).

sulting high-resolution tephrochronological framework will help decipher the temporal and spatial complexity of archaeological records, tectonic outbursts, volcanic impact, and environmental change for this highly dynamic area. In addition, identification of tephra layers contributes to a better understanding of regional eruptive histories, magnitudes of past eruptions, volcanic hazards, and magma origin in Kamchatka. 


\section{Volcanoes of Kamchatka and studied samples}

The Kamchatka Peninsula overlies the northwestern margin of the subducting Pacific plate and is one of the most volcanically and tectonically active regions in the world (e.g., Gorbatov et al., 1997). Kamchatka hosts more than 30 large active volcanoes, 40 calderas, and hundreds of monogenetic vents grouped into two major volcanic belts running northeast-southwest along the peninsula, which are the Eastern Volcanic Belt and the Sredinny Range (SR) (Fig. 1). The Eastern Volcanic Belt includes the volcanic front (VF) and rear arc (RA) in the southern $\left(51-53^{\circ} \mathrm{N}\right)$ and central $\left(53-55^{\circ} \mathrm{N}\right)$ segments, and the volcanic zone of the Central Kamchatka Depression (CKD) in the northern segment (55$57^{\circ} \mathrm{N}$ ). Definition of VF and RA volcanoes varies in published studies. In this work, VF volcanoes are defined as those located at the closest distance to the deep-sea trench along the volcanic arc. RA volcanoes are located behind the frontal volcanoes. The current configuration of the volcanic belts is believed to have existed since ca. $2.5 \mathrm{Ma}$ (Avdeiko et al., 2007; Lander and Shapiro, 2007; Legler, 1977; Volynets, 1994).

The products of the continuous explosive volcanism in Kamchatka during the last $2.5 \mathrm{Ma}$ are not equally represented in the depositional record. Holocene tephra layers mantle the topography and, being interlayered with paleosol or peat horizons, form a sequence that provides a nearly continuous record of the Holocene explosive activity (e.g., Bazanova and Pevzner, 2001; Braitseva et al., 1998, 1996, 1995, 1997; Kyle et al., 2011; Pevzner, 2010; Pevzner et al., 1998; Ponomareva et al., 2015a, b, 2017). Earlier pre-Holocene pyroclastic products are mostly ignimbrite (pumiceous or welded tuffs), which survived through glacial stages better than loose pyroclastics and in many cases experienced alteration (Bindeman et al., 2019, 2010; Ponomareva et al., 2018; Seligman et al., 2014). These deposits are partly eroded by glacial processes, buried by younger deposits, and/or covered with dense vegetation, which hampers their identification.

TephraKam database provides data on volcanic glass composition from 65 volcanic centers in Kamchatka. Of these centers, 43 were active in the Holocene and the remaining 22 centers ceased their activity prior to the Holocene. Some volcanic centers are individual volcanic cones (e.g., Iliinsky), calderas (e.g., Kurile Lake caldera), monogenetic lava fields (e.g., Tolbachik lava field), or monogenetic vents (cinder cones and craters), while other centers combine several volcanoes and/or calderas (e.g., Karymsky center). The latter approach was used in cases when thick local pyroclastic deposits could not be unambiguously assigned to a certain volcano within the volcanic cluster. We define the source vent within the volcanic center where possible (e.g., Karymsky/Polovinka caldera). Eight ignimbrite units come from unknown sources so we use coordinates of their samples instead of vent coordinates.
We have analyzed glass from 487 samples, including 11 replicate samples marked as "-rep" in the database. Overall, our samples characterize about 300 individual explosive eruptions. A total of 298 samples come from tephra fall deposits, 187 are from ignimbrite units (42 of them welded), and 2 are from lava. Our sampling covers all the Quaternary volcanic belts: $25 \%$ of the samples are from VF, $27 \%$ are from RA, $40 \%$ are from CKD, and $8 \%$ are from the Sredinny Range. The coverage among the volcanic centers is not uniform: some volcanoes are characterized by only one sample while others are densely sampled and analyzed. The sampling density partly reflects the amount of large explosive eruptions from a certain volcano. The analyzed samples span an age interval from the Miocene (ca. $6 \mathrm{Ma}$ ) to recent times (Fig. 2). About $60 \%$ of samples and data presented in this database are from the Holocene and characterize all large explosive eruptions in Kamchatka during this time (Braitseva et al., 1995, 1997; Ponomareva et al., 2013b, 2015b), as well as many moderate-size eruptions. Ages, tephra dispersal areas, and volumes for most of the Holocene eruptions have already been published (Braitseva et al., 1998, 1996, 1997; Kyle et al., 2011; Ponomareva et al., 2017; Zaretskaya et al., 2007). The pre-Holocene record of explosive eruptions is spotty, and its representativeness decreases with increasing rock age (Fig. 2). Most of the pre-Holocene samples characterize ignimbrites associated with large (diameter 5-40 km) collapsed calderas. A total of 69 of the $\sim 200$ Pleistocene samples characterize 38 eruptions dated with the help of radiocarbon, ${ }^{39} \mathrm{Ar} /{ }^{40} \mathrm{Ar}$, or age modeling while the rest of the samples provide information about earlier unreported eruptions. Analyzed samples were collected between 1975 and 2016 by 22 contributors; the largest collections come from the authors of this paper.

\section{Methods and database structure}

\subsection{Sample preparation}

Tephra samples have been prepared using our original technique, developed in the past 20 years at GEOMAR (Kiel) and the Vernadsky Institute (Moscow). The technique aims for uncomplicated, time- and material-effective preparation of many tephra samples for microanalytical work. The technique applies no strong heating $\left(>50^{\circ} \mathrm{C}\right)$ and no acid leaching, which may cause chemical modification of tephra glasses (e.g., Hunt and Hill, 1996). All material used for preparation were thoroughly tested to exclude those causing chemical contamination of polished glass surface.

The samples have been cleaned in water to wash out clay and the finest $(<5 \mu \mathrm{m})$ fraction and then dried. Fineand medium-grained ash has been mounted without splitting into fractions and additional crushing. Lapilli and welded tuffs have been carefully crushed in a hand mortar and then mounted. The samples were mounted in $25 \mathrm{~mm}$ diameter, $4 \mathrm{~mm}$ thick Plexiglas holders with 12 and 16, respectively, 


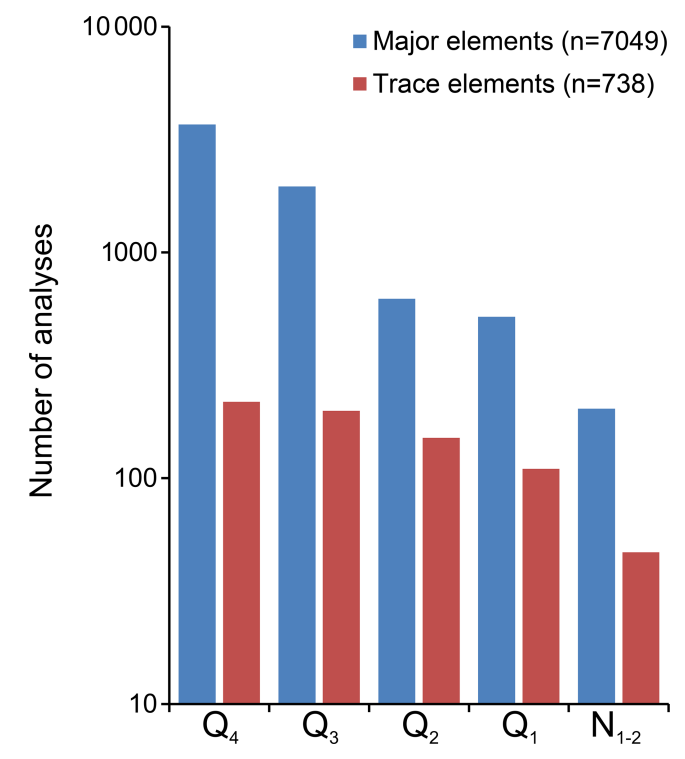

Figure 2. Number of single-spot major and trace element analyses of glass from tephra and welded tuffs of different age groups included in the TephraKam database. Note the logarithmic vertical scale.

3 and $2 \mathrm{~mm}$ cells (holes through holder). Before mounting, the holders were attached to a hard plate using $25 \mathrm{~mm}$ double-sided glue tape rings from Plano $\mathrm{GmbH}$ for electron microscopy, which have a thin but strongly adhesive glue layer and very flat surface with unevenness in the range of ca. $10 \mu \mathrm{m}$. Two-component epoxy resin, EpoThin from Buehler, was used in the course of this study. We found this type of epoxy was particularly suitable for tephra studies as the epoxy has sufficiently low viscosity to impregnate fine-grained samples and very good vacuum properties. In addition, the epoxy is relatively hard and thus well polished, transparent, and colorless. This type of epoxy also contains analytically negligible (below analytical detection limit) amounts of most major and trace elements, except $\sim$ $3 \mathrm{wt} \%$ chlorine. After hardening, the mounts were removed from the glue tape, cleaned with ethanol and water, and then ground wet using 600-1200 grit $\mathrm{SiC}$ sandpaper and polished by hand on stiff paper (unused computer punch card from the mid-20th century) using KEMET diamond pastes of 6, 3, and $1 \mu \mathrm{m}$ grain size. Final polishing was done with $0.05 \mu \mathrm{m}$ Buehler $\mathrm{Al}_{2} \mathrm{O}_{3}$ suspension in water on a soft tissue disk for $1 \mathrm{~min}$. Polishing on a hard surface is crucial for the preparation of very fine tephras as it creates a maximum flatness of small single glass shards, ensuring a high quality of analysis of small glass particles by electron probe. The samples were finally washed by brush in deionized water, dried, and photographed under optical microscope.

\subsection{Electron probe microanalysis (EPMA)}

In this study, EPMA data have been obtained following published recommendations for the analytical conditions, primary and secondary reference materials, the number of analyses, and other factors and procedures, which may influence the quality of EPMA data for tephra glasses and their interpretation (Froggatt, 1992; Morgan and London, 1996, 2005; Hunt and Hill, 2001; Turney et al., 2004; Kuehn et al., 2011; Lowe et al., 2017). A particularly influential study was an intercomparison of electron microprobe data for volcanic glasses between different labs (Kuehn et al., 2011), which confirmed a high quality of our data (GEOMAR lab is no. 12 in Kuehn et al., 2011) and allowed us to further improve our EPMA protocol.

The glasses were analyzed at GEOMAR (Kiel, Germany) using a JEOL JXA 8200 electron microprobe equipped with five wavelength dispersive spectrometers, including three high-sensitivity instruments (two PETH and a TAPH). The analytical conditions were $15 \mathrm{kV}$ accelerating voltage, $6 \mathrm{nA}$ current, and $5 \mu \mathrm{m}$ electron beam size for all analyses. The current and size conditions correspond to the current density of $0.076 \mathrm{nA} \mathrm{\mu m}^{-2}$, which is within the recommended range $\left(<0.1 \mathrm{nA} \mathrm{\mu m}^{-2}\right)$ to minimize the Na loss during analysis, especially in a combination with short counting time for $\mathrm{Na}$ (Morgan and London, 1996, 2005; Kuehn et al., 2011). Counting times in the latest version of the program are 5 and $10 \mathrm{~s}$ (peak and background, respectively) for $\mathrm{Na} ; 20$ and $10 \mathrm{~s}$ for $\mathrm{Si}, \mathrm{Al}, \mathrm{Mg}, \mathrm{Ca}$, and $\mathrm{P} ; 30$ and $15 \mathrm{~s}$ for $\mathrm{Fe}, \mathrm{K}, \mathrm{Ti} \mathrm{Cl}$, and S; 40 and $20 \mathrm{~s}$ for F; and 60 and $20 \mathrm{~s}$ for Mn. The counting times have been optimized several times in the course of this study. The changes are reported in TephraKam Table 1a. The changes have not affected the data accuracy for most elements, but the precision of single-point analyses has improved. Decreasing counting time for $\mathrm{Na}$ from 20 to $5 \mathrm{~s}$ in 2010, which was aimed at minimizing loss of this element during analysis, resulted in analytical precision that was about 2 times lower for single-point $\mathrm{Na}$ analyses (Morgan and London, 1996), but the accuracy of $\mathrm{Na}$ analysis was improved and became less dependent on the reference material for standardization.

Basaltic glass (USNM 113498/1 VG-A99) for Ti, Fe, Mg, $\mathrm{Ca}$, and P; rhyolitic glass (USNM 72854 VG568) for Si, Al, $\mathrm{Na}$, and $\mathrm{K}$; scapolite (USNM R6600-1) for $\mathrm{S}$ and $\mathrm{Cl}$ (all from the Smithsonian collection of natural reference materials; Jarosewich et al., 1980); comendite obsidian KN-18 (Nielsen and Sigurdsson, 1981; Mosbah et al., 1991) for F; and synthetic rhodonite for Mn were used for calibration and monitoring of routine measurements. Two to three analyses of all standard glasses and scapolite were performed at the beginning of analytical session, after every 50-60 analyses and at the end. The data reduction included online CITZAF correction and small drift correction for systematic deviations (if any) from the reference values obtained on standard materials. The latter correction has not exceeded a few relative 
percent for all elements and allowed us to achieve the best possible accuracy and precision. The correction resulted in a very minor change of the mean concentrations but allowed $20 \%-40 \%$ improvement of the analytical precision (2 SD; $\mathrm{SD}$ is sample standard deviation) and the shape of data distribution, making it closer to Gaussian distribution (see the Supplement to Ponomareva et al., 2017).

The glass analyses used in this study were obtained in the period from 2009 to 2019. The summary of data for reference materials collected over this period of time is presented in TephraKam Table 1b (Portnyagin et al., 2019). The data include results obtained on major reference glasses and minerals, which were used in calibration of quantitative microprobe measurements (USNM 72854 VG568, USNM 113498/1 VG-A99, USNM R6600-1, KN18), and also results obtained for other reference materials analyzed as unknown in the course of our study. The latter include natural glasses USNM 111240/52 VG-2 (Jarosewich et al., 1980); Lipari obsidian (Hunt and Hill, 1996); Mt. Ediza Sheep Track tephra; Laki 1783 AD tephra; Old Crow tephra (Kuehn et al., 2011); and glasses made of natural rock powders ATHOG, BM90/21-G, GOR128-G, KL2-G, StHs60/8-G, ML3B-G (Jochum et al., 2006), and artificial glass NIST SRM 612 (Jochum et al., 2011). The data demonstrate remarkable agreement with recommended concentrations for all elements and thus excellent accuracy of our data, which reproduces reference concentrations within the reported $2 \mathrm{SD}$ in nearly all cases. The latter is also true for concentrations, which significantly exceed the concentrations in reference glasses used for calibration. This is illustrated, for example, by analyses of $\mathrm{Na}_{2} \mathrm{O}$ in NIST SRM 612 glass $(13.70 \pm 0.30 \mathrm{wt} \%$ recommended vs. $13.73 \pm 0.40 \mathrm{wt} \%$ measured) and $\mathrm{MgO}$ in GOR128-G glass $(26.00 \pm 0.30 \mathrm{wt} \%$ recommended vs. $25.66 \pm 0.68 \mathrm{wt} \%$ measured).

Precision of single-point analyses depends on the element concentration and analytical conditions for every element. Assuming that the reference materials used in this study were perfectly homogeneous (which may be not true for natural glasses containing microlites of minerals), the precision of single-point analysis of typical rhyolite can be assessed from $2 \mathrm{SD}$ of the long-term mean concentrations obtained for glass USNM 72854 VG568 or Lipari obsidian. Precision of singlepoint basaltic glass analysis can be evaluated from the data on glasses USNM 113498/1 VG-A99 or USNM 111240/52 VG-2. For more precise determination of a single-point analytical precision, we provide TephraKam Table 1c (Portnyagin et al., 2019), where the precision for every element is calculated based on element concentration in glass, taking into account long-term reproducibility of reference materials. Correlation of the oxide concentrations in reference materials plotted against long-term relative standard deviation (2 RSD, \%) allows for estimating analytical detection limits and finding element concentrations at which 2 RSD approaches $100 \%$ (TephraKam Table 1c).
During the subsequent data reduction, we excluded analyses with the totals lower than $90 \mathrm{wt} \%$, which resulted from possible unevenness of sample surface, entrapment of voids, or epoxy during analysis of very small glass fragments. The latter has been also identified by unusually high measured chlorine concentrations, resulting from entrapment of epoxy resin during analysis (see Sect. 3.1). Analyses contaminated by occasional entrapment of crystal phases, usually microlites of plagioclase, pyroxene, or Fe-Ti oxides, were mostly identified and excluded on the basis of excessive concentrations of $\mathrm{Al}_{2} \mathrm{O}_{3}, \mathrm{CaO}$, or $\mathrm{FeO}$ (and $\mathrm{TiO}_{2}$ ), respectively, compared to the prevailing composition of glasses in every sample. Because volcanic glasses can be hydrated over time during post-magmatic interaction with meteoric water or seawater or contain significant but variable amounts of $\mathrm{H}_{2} \mathrm{O}$ that were not completely degassed during the eruption, all analyses were then normalized to an anhydrous basis, accounting for the presence of halogens $(\mathrm{Cl}, \mathrm{F})$ substituting for $\mathrm{O}$.

\subsection{Laser ablation inductively coupled plasma mass spectrometry (LA-ICP-MS)}

In the past 25 years LA-ICP-MS became a common technique to quantify concentrations of a wide range of trace elements in tephra glasses (e.g., Westgate et al., 1994; Pearce et al., 1996, 2007, 2014; Tomlinson et al., 2010; Kimura and Chang, 2012; Maruyama et al., 2016; Lowe et al., 2017). The LA-ICP-MS technique adopted for this study and its development were based on the principal results and recommendations from the previous works and our own experimental results. All the trace element analyses were obtained at the Institute of Geosciences, CAU Kiel, Germany. Conditions of analysis are summarized in TephraKam Table 1d (Portnyagin et al., 2019).

Before 2017, analyses were performed using a quadrupole-based ICP-MS (Agilent 7500s) and a Coherent GeoLas ArF $193 \mathrm{~nm}$ Excimer LA system. In situ microsampling was done with $24-50 \mu \mathrm{m}$ pit size and $10 \mathrm{~Hz}$ pulse frequency at $5-10 \mathrm{~J} \mathrm{~cm}^{-2}$ fluence. Analyses were performed using a large volume ablation cell (ETH Zürich, Switzerland) (Fricker et al., 2011). The generated aerosol was transported with $0.75 \mathrm{~L} \mathrm{~min}^{-1} \mathrm{He}$ and mixed with $0.6 \mathrm{~L} \mathrm{~min}^{-1} \mathrm{Ar}$ prior to introduction into the ICP. The ICP-MS was operated under standard conditions at $1500 \mathrm{~W}$ and optimized for low oxide formation (typically $\mathrm{ThO} / \mathrm{Th} \leq 0.4 \%)$ and robust plasma $(\mathrm{U} / \mathrm{Th} \approx 1) . \mathrm{Ca}, \mathrm{Ti}$, $\mathrm{Si}$, and 30 trace elements were analyzed. The calibration was based on NIST SRM 612 glass standard (Jochum et al., 2011) and matrix-corrected using ATHO-G and KL2-G glasses (Jochum et al., 2006). The measured intensities were converted to element concentrations using a conventional approach (Longerich et al., 1996; Pearce et al., 1996), with ${ }^{43} \mathrm{Ca}$ as the internal standard and the anhydrous normalized $\mathrm{CaO}$ from EPMA data. Initial data reduction was performed in Glitter software (Griffin et al., 2008) setting integration 
windows of time-resolved data for background $(20 \mathrm{~s})$ and variable times depending on signal duration from individual tephra shards. Si and Ti concentrations obtained by LA-ICPMS were compared to microprobe data, and the LA-ICP-MS analyses that deviate from EPMA data for these elements by more than $20 \%$ relative were rejected. The threshold value of $20 \%$ corresponds to $\sim 3 \mathrm{RSD}$ obtained for $\mathrm{Si}$ and Ti on reference glasses using $24 \mu \mathrm{m}$ pit size (TephraKam Table 1e).

Beginning from January 2017, the analyses were obtained using a new ICP-MS Agilent 7900s and a Coherent GeoLas $\operatorname{ArF} 193 \mathrm{~nm}$ Excimer LA system operated with a fluence of $5 \mathrm{~J} \mathrm{~cm}^{-2}$, at a repetition rate of $10 \mathrm{~Hz}$ and a $15-24 \mu \mathrm{m}$ ablation craters. Analyses were performed using the same large volume ablation cell as before (ETH Zürich, Switzerland) but modified for fast washout. Helium $\left(0.7 \mathrm{~L} \mathrm{~min}^{-1}\right)$ with addition of $14 \mathrm{~mL} \mathrm{~min}^{-1} \mathrm{H}_{2}$ was used as carrier gas. The carrier gas was mixed with $\mathrm{Ar}\left(\sim 1 \mathrm{~L} \mathrm{~min}^{-1}\right)$ prior to introduction to the ICP-MS. A total of 10 major elements ( $\mathrm{Si}, \mathrm{Ti}, \mathrm{Al}, \mathrm{Fe}$, $\mathrm{Mn}, \mathrm{Mg}, \mathrm{Ca}, \mathrm{Na}, \mathrm{K}, \mathrm{P}$ ) and 31 trace elements were analyzed. Analyses included $20 \mathrm{~s}$ background (laser off) and $30 \mathrm{~s}$ signal (laser on) measurements. Dwell time for different elements varied from 5 to $20 \mathrm{~ms}$ depending on their abundance. One complete measurement cycle lasted $0.607 \mathrm{~ms}$, and initial data reduction was performed in Glitter software (Griffin et al., 2008), which included manual selection of integration windows and preliminary calibration. The typical integration intervals for tiny tephra shards were 6-10 s and included 1017 cycles. The intensities corrected for background and averaged over the selected intervals were normalized to the intensity of ${ }^{43} \mathrm{Ca}$ isotope and converted to concentrations by matching the sum of major element oxides to $100 \mathrm{wt} \%$ (Liu et al., 2008; Pettke et al., 2004). The calibration and correction of instrumental drift used data on ATHO-G reference glass, which was measured in duplicate after every 18 points on unknown samples. The reference concentrations of all elements, except $\mathrm{Na}$, in ATHO-G were used following Jochum et al. (2006). Na concentrations was accepted to be $4.1 \mathrm{wt} \%$, ca. $10 \%$ higher, relative to those reported by Jochum et al. (2006) to reproduce $\mathrm{Na}$ in other reference glasses analyzed by LA-ICP-MS in this study (TephraKam Table 1d, e) and better comply with Na obtained by electron microprobe (TephraKam Table 1b). Sc concentrations were corrected for $\mathrm{SiO}^{+}$interference using reference glasses with known $\mathrm{Sc}$ and variable $\mathrm{SiO}_{2}$ content. The data were further filtered for inclusion of phenocryst phases by comparison of major element concentrations with those obtained by EPMA, and obvious outliers were rejected to leave only glass analyses.

During all periods of data collection from 2011 to 2019, BCR2-G, KL2-G, and STHS60/8-G glasses (Jochum et al., 2006) were analyzed as unknown in one series with the samples (TephraKam Table 1e). The data confirms good consistency of the entire dataset and no bias related to periodic instrumental upgrades. Based on these data, the analytical pre- cision and accuracy are typically between $\pm 2 \%$ and $8 \%$ for $20 \mathrm{~s}$ long analyses, but the precision might be reduced for very short analyses of tiny glass shards and for elements occurring at concentrations below $0.1 \mathrm{ppm}$.

Overall, the data obtained since 2017 using the very sensitive modern instrument Agilent 7900 and after implementation of additional improvements (modified cell, addition of $\mathrm{H}_{2}$ in carrier gas) are more accurate compared to earlier data for the same spot size of $24 \mu \mathrm{m}$. Older data obtained with $50 \mu \mathrm{m}$ spot have comparable precision to the most recent data. However, some former data can be affected by entrapment of crystal phases (e.g., Pearce et al., 2014) that was impossible to identify by only using data on $\mathrm{Ti}$ and $\mathrm{Si}$ concentrations. Thus, outliers in pre-2017 data should be considered with care. Besides a smaller laser beam, the post2017 data were quantified using a more efficient approach by normalizing oxides to $100 \%$. These data are directly comparable with EPMA data for all elements except volatiles F, $\mathrm{Cl}$, and $\mathrm{S}$. Thus, contamination of these analyses by occasional entrapment of crystal phases is excluded. The recent LA-ICP-MS data also provide accurate concentrations of Ti, $\mathrm{Mn}$, and $\mathrm{P}$, occurring in silicic glasses in concentrations approaching and below the detection limit of our EMP analyses ( $0.02 \mathrm{wt} \%-0.03 \mathrm{wt} \%$ for these elements).

\subsection{Tephra ages}

Knowledge of tephra ages (or at least approximate age ranges) is crucial for their use as marker horizons. For many tephras in our database, the age estimates are available from published data (Auer et al., 2009; Bazanova and Pevzner, 2001; Bazanova et al., 2019; Bindeman et al., 2019, 2010; Braitseva et al., 1998, 1991, 1995; Churikova et al., 2015; Cook et al., 2018; Dirksen, 2009; Dirksen and Bazanova, 2009; Dirksen and Melekestsev, 1999; Florensky, 1984; Kozhurin et al., 2006; Masurenkov, 1980; Melekestsev et al., 1992, 1995; Pevzner, 2015; Plechova et al., 2011; Ponomareva et al., 2018, 2013b, 2017, 2015b, 2006; Ponomareva, 1990; Seligman et al., 2014; Volynets et al., 1998; Zaretskaia et al., 2001; Zaretskaya et al., 2007; Zelenin et al., 2020). In this case, we report bibliographical references and details on the age estimates and dating techniques. The majority of previously reported tephra ages were obtained by radiocarbon dating of host sediments. The ages are usually published as uncalibrated ${ }^{14} \mathrm{C}$ dates. In the TephraKam database (Portnyagin et al., 2019), the published ${ }^{14} \mathrm{C}$ dates have been recalculated to calibrated ages before present (cal yr BP) with $95 \%$ error interval using the most recent IntCal13 calibration curve (Reimer et al., 2013). Some calibrated ages are based on poorly documented ${ }^{14} \mathrm{C}$ dates and reported as approximate ages (" $\sim$ " symbol) or as an age range. Holocene tephras in northern Kamchatka, as well as some Holocene marker tephras, were dated with the help of Bayesian age model combining 223 individual ${ }^{14} \mathrm{C}$ dates (Ponomareva et al., 2017). One Holocene tephra (KHG from Khangar vol- 
cano) was found in the Greenland ice and dated with the help of the Greenland Ice Core Chronology 2005 (GICC05, Cook et al., 2018; Rasmussen et al., 2006; Vinther et al., 2006). A total of 21 welded tuff units were dated by ${ }^{39} \mathrm{Ar} /{ }^{40} \mathrm{Ar}$ (Bindeman et al., 2019, 2010; Seligman et al., 2014). For undated samples, the age estimates were derived from their stratigraphic relationships with the dated ones. Designated age group is provided for all samples according to the geologic timescale.

\subsection{Database structure}

The TephraKam database is provided in Excel 2016 file (.xlsx) and consists of six folders (TephraKam Tables 2af, Portnyagin et al., 2019): (a) comments, (b) volcanoes, (c) sample description, (d) major elements, (e) trace elements, and (f) discrimination diagrams. Table $2 \mathrm{a}$, comments, explains abbreviations of columns in the data tables. Table $2 b$, volcanoes, contains information about volcanic centers of Kamchatka, from which volcanic glass data exist and are presented in the database. Table $2 \mathrm{c}$, sample description, includes coordinates, information of sample age, outcrop, type of material (ash, pumice, and welded tuff), collector's name, and other information including data for source volcano via link to Table 2 b. Table $2 d$, major elements, contains EPMA data on individual glass shards from samples studied and related information. Table $2 \mathrm{e}$, trace elements, contains LA-ICP-MS major and trace element data on single glass shards, information about the dates and conditions of LAICP-MS analysis, trace element concentrations normalized to mantle composition, and some element ratios for plotting the data. The tables are linked to each other so that any changes in volcano or sample description will be seen in geochemical data tables. Table 1f, discrimination diagrams, contains sample plots and coordinates of corner points to draw compositional fields of the modern volcanic zones in Kamchatka using coordinates $\mathrm{Nb} / \mathrm{Y}$ vs. $\mathrm{La} / \mathrm{Y}$ and $\mathrm{Nb} / \mathrm{Y}$ vs. Th/Y.

\section{Data overview}

\subsection{Spatial and temporal variations in volcanic glass compositions}

Major element data are available for all samples and are comprised of 7049 individual analyses. Trace elements are available for 114 samples and include 738 individual analyses. About $30 \%$ of the major element data have already been published, e.g., for the Shiveluch eruptions (Ponomareva et al., 2015b); the Ushkovsky eruptions (Ponomareva et al., 2013b); and a part of the Bezymianny and Tolbachik eruptions (Ponomareva et al., 2017). The majority of the trace element data are presented here for the first time.

An overview of the available major element data is shown in Fig. 3, a common classification diagram for island arc rocks in coordinates $\mathrm{SiO}_{2}$ vs. $\mathrm{K}_{2} \mathrm{O}$ (Gill, 1981; Le Maitre et al., 2002; Peccerillo and Taylor, 1976). In this diagram, lines dividing low- $\mathrm{K}_{2} \mathrm{O}$, medium- $\mathrm{K}_{2} \mathrm{O}$, and high- $\mathrm{K}_{2} \mathrm{O}$ compositions are drawn along typical trends of magma fractionation from basalts to rhyolites. Thus, this diagram is useful to access the extent of magma fractionation and relative enrichment in $\mathrm{K}_{2} \mathrm{O}$ of parental magma and/or source rock. Basaltic glasses are very rare in tephra from Kamchatka. The vast majority of glasses have basaltic andesite, andesite, dacite, and rhyolite low- to high- $\mathrm{K}_{2} \mathrm{O}$ compositions. The compositions are not uniformly distributed in $\mathrm{SiO}_{2}-\mathrm{K}_{2} \mathrm{O}$ coordinates. Some compositions are more common; the others are rather rare. For example, dacite and rhyolite tephra glasses with $\mathrm{K}_{2} \mathrm{O} \sim 2$ wt $\%$ and $\mathrm{SiO}_{2}$ of 68 wt $\%-72$ wt $\%$, very low- $\mathrm{K}_{2} \mathrm{O}$ rhyolites, and alkali rhyolites with $\mathrm{K}_{2} \mathrm{O}>5 \%$ are extremely rare or unknown in Kamchatka. In turn, medium- $\mathrm{K}_{2} \mathrm{O}$ rhyolite glasses with $\mathrm{K}_{2} \mathrm{O} \sim 3 \mathrm{wt} \%$ and $\mathrm{SiO}_{2}$ of $\sim 75 \mathrm{wt} \%$ are very common and characterize many eruptions from all volcanic zones.

The compositions of glasses are grouped in Fig. 3 according to their source volcano location in Kamchatka (Fig. 3a), age (Fig. 3b), type of volcano (Fig. 3c), and type of sample (Fig. 3d). Figure 3a-c show glasses taken only from tephra; Fig. 3d compares glasses taken from tephra and welded tuffs. Glasses from VF are represented by a full range of compositions from basaltic andesites to rhyolites and belong to low$\mathrm{K}_{2} \mathrm{O}$ and medium- $\mathrm{K}_{2} \mathrm{O}$ series. $\mathrm{RA}$ glasses have medium- and high- $\mathrm{K}_{2} \mathrm{O}$ compositions and overlap only marginally with VF glasses. CKD glasses have similar range of compositions with RA glasses, although medium- $\mathrm{K}_{2} \mathrm{O}$ rhyolite glasses similar to VF glasses are abundant in CKD (e.g., Shiveluch volcano). SR glasses exhibit compositional bimodality. Compositions with $\mathrm{SiO}_{2}$ from $65 \mathrm{wt} \%$ to $72 \mathrm{wt} \%$ are not known in the SR. The glasses have medium- $\mathrm{K}_{2} \mathrm{O}$ (some SR rhyolites) and predominantly high- $\mathrm{K}_{2} \mathrm{O}$ compositions. The glass compositions do not exhibit clear temporal variability, suggesting similar composition of erupted magmas since at least Middle Pleistocene (Fig. 3b). The compositions of tephra glasses from complex volcanoes and calderas are similarly variable and cover all compositional ranges. Tephra glasses from monogenetic volcanoes tend to have either the most mafic basaltic andesite compositions (basaltic cinder cones) or rhyolitic compositions (explosive craters). Some intermediate compositions are also known but are not as abundant as previously mentioned types (Fig. 3c). In addition to tephra glasses, the database includes glasses from welded tuffs and obsidian, which are important for characterizing the oldest explosive eruptions in Kamchatka. In comparison with tephras, welded tuff glasses tend to have $\mathrm{SiO}_{2}$-rich dacite and rhyolite compositions, although samples with some andesitic glasses are also present (Fig. 3d). Many welded tuffs have compositions with $\mathrm{K}_{2} \mathrm{O}>5 \mathrm{wt} \%$, which is higher than in the majority of tephra glasses. This $\mathrm{K}_{2} \mathrm{O}$ enrichment is most likely related to secondary alteration of glass, as discussed in more detail in Sect. 4.3. 

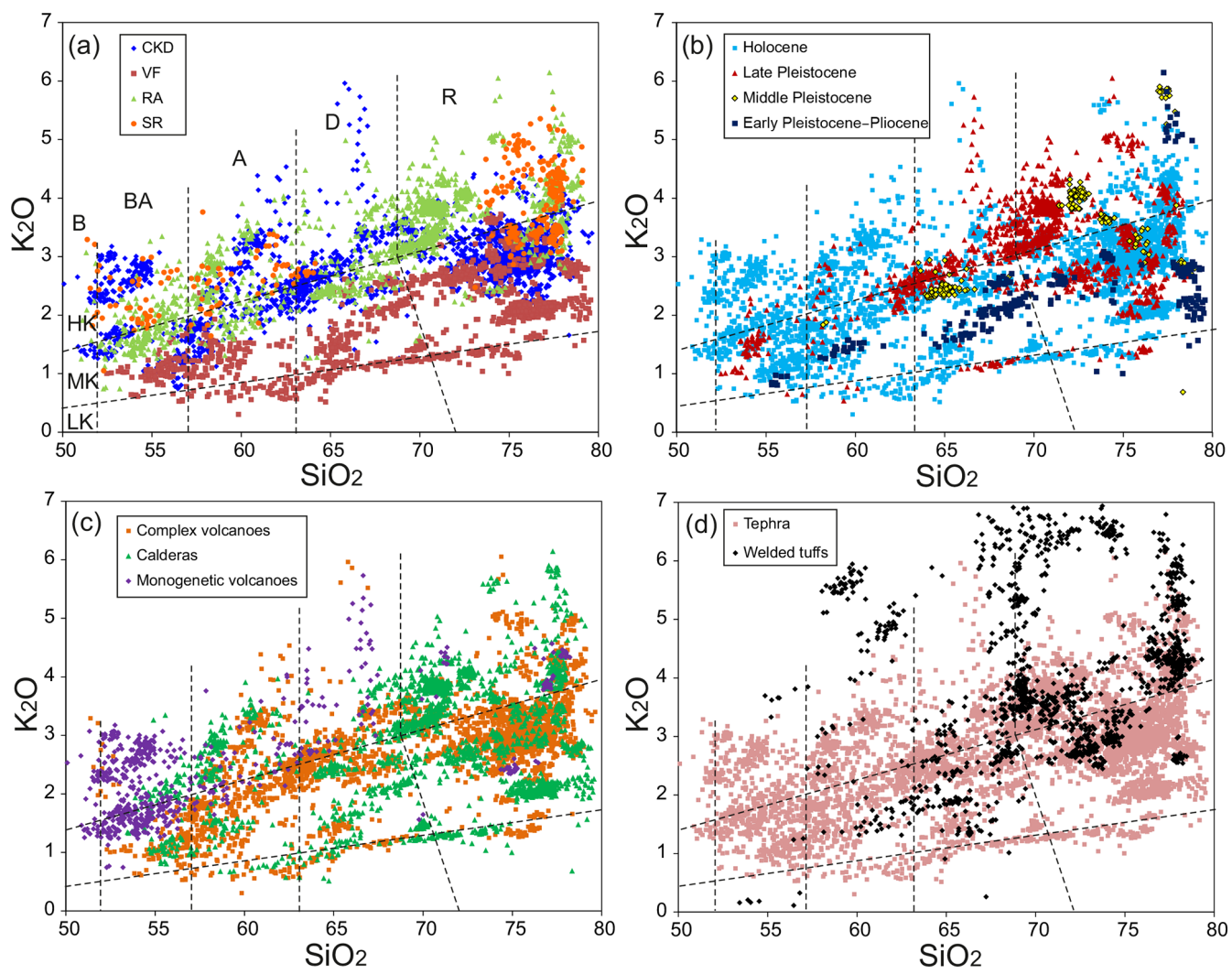

Figure 3. $\mathrm{SiO}_{2}-\mathrm{K}_{2} \mathrm{O}$ variations in glasses. The glasses are grouped according to volcanic zone (a), age (b), type of volcano (c), and rock type (d). Dashed lines divide fields of low- $\mathrm{K}_{2} \mathrm{O}(\mathrm{LK})$, medium- $\mathrm{K}_{2} \mathrm{O}(\mathrm{MK})$, and high- $\mathrm{K}_{2} \mathrm{O}(\mathrm{HK})$ basalts (B), basaltic andesites (BA), andesites (A), dacites (D), and rhyolites (R) following Le Maitre et al. (2002). The line dividing fields of dacite and rhyolite is drawn for the case of $\mathrm{Na}_{2} \mathrm{O}$ content of $5 \mathrm{wt} \%$, which is typical for high-silica glasses from Kamchatka.

Data on concentrations of trace elements in glasses add significant information, which are highly valuable for precise identification of volcanic sources, as well as for petrological and geochemical applications of this database. The data for Ti, Mn, and P obtained by LA-ICP-MS are generally of higher precision in comparison to EPMA data, particularly for glasses with concentrations of these elements below $500 \mathrm{ppm}(0.05 \mathrm{wt} \%)$, approaching the detection limit of EPMA.

Trace elements provided in this database belong to different groups with contrasting geochemical properties in magmatic systems and therefore provide different geochemical information. Behavior of Sr, Ti, V, Sc, P, Zr, Hf, and heavy rare earth elements (heavy REEs: Eu, Gd, Tb, Dy, $\mathrm{Ho}, \mathrm{Er}, \mathrm{Tm}, \mathrm{Yb}, \mathrm{Lu})$ is strongly controlled by solid crystalline phases. When plagioclase ( $\mathrm{Sr}, \mathrm{Eu}), \mathrm{Fe}-\mathrm{Ti}$ oxides (Ti, $\mathrm{V})$, pyroxene $(\mathrm{Sc})$, apatite $(\mathrm{P})$, zircon $(\mathrm{Zr}, \mathrm{Hf})$, and amphibole (heavy REEs) crystallize from magmas, these elements behave as "compatible elements", and their concentrations decrease in residual melts. In contrast, elements $\mathrm{Rb}, \mathrm{Ba}$, Th, $\mathrm{Nb}, \mathrm{Ta}, \mathrm{Pb}$, and light REEs ( $\mathrm{La}, \mathrm{Ce}, \mathrm{Pr}, \mathrm{Nd}, \mathrm{Sm}$ ) behave as "incompatible elements" in most magmas of Kamchatka because they are not concentrated in solid phases and en- rich in residual melt. Systematics of incompatible elements can be informative of the magma source composition and subduction-related parameters, such as, for example, the distance from volcano to subducting plate (e.g., Volynets et al., 1994; Churikova et al., 2001; Duggen et al., 2007). The ratios between incompatible elements do not change as magma fractionates and are instructive for identifying the source volcano of variably fractionated melts. This information is quite unique in comparison to the systematics of major elements, which, in contrast to incompatible trace elements is largely related to the conditions of magma storage and also to syneruptive crystallization and magma mixing (Cashman and Edmonds, 2019; Ponomareva et al., 2015a).

Although detailed evaluation of trace element systematics in Kamchatka glasses is beyond the scope of this work, in Fig. 4 we illustrate some regularity in trace element composition of tephra glasses from different volcanic zones in Kamchatka, which can help identify source volcano or at least volcanic zone for tephra of unknown provenance. In this diagram, we show only Holocene and Late Pleistocene samples as their source volcanoes are reliably constrained, and the available data are the most representative compared to older volcanic rocks. 

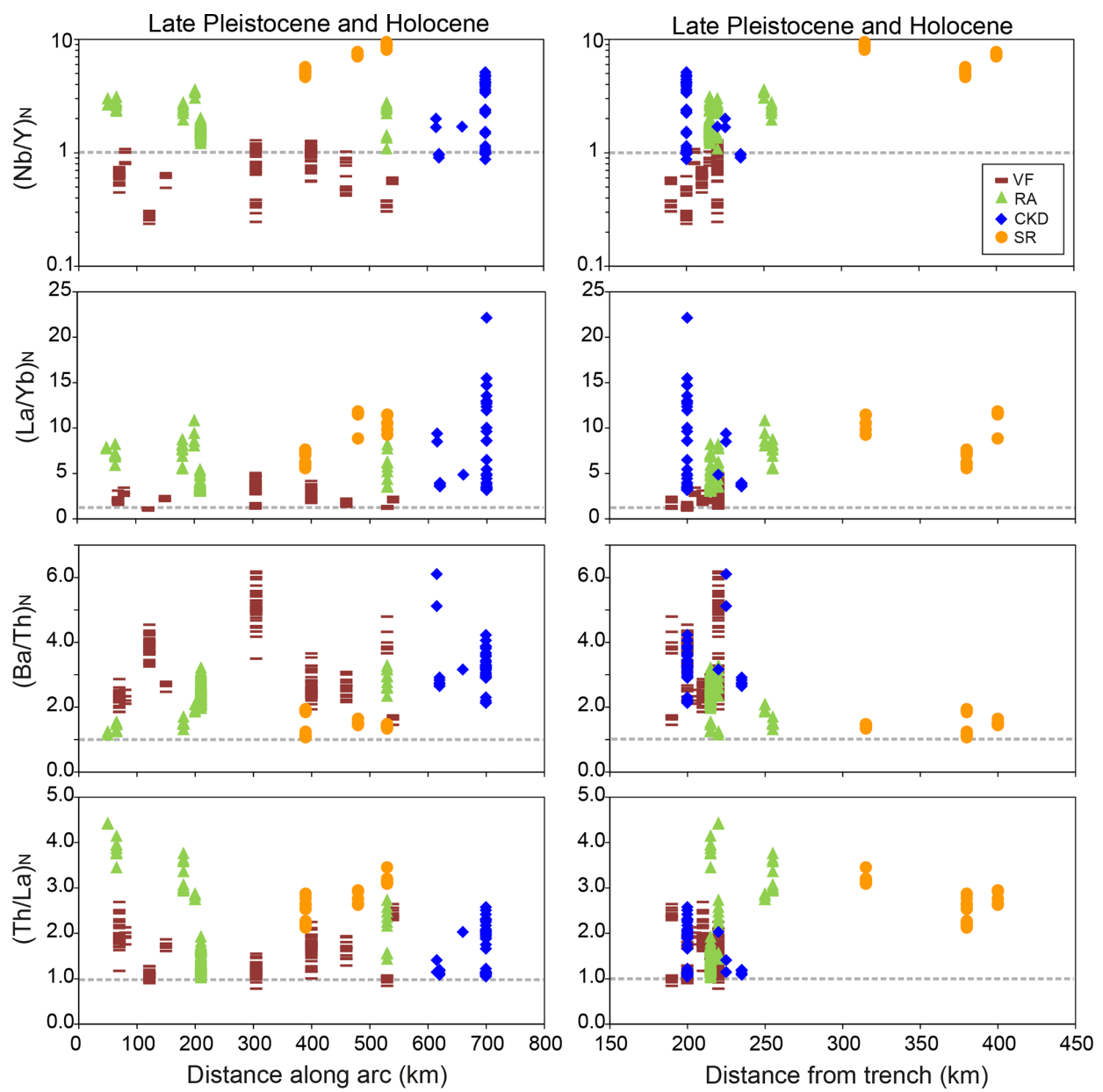

Figure 4. Trace element variations in Holocene and late Pleistocene tephra glasses south to north (left) and across (right) the Kamchatka volcanic belts. Trace element ratios are normalized to primitive mantle values (McDonough and Sun, 1995). Nb/Y and La/Yb ratios reflect mantle source depletion and enrichment (e.g., Pearce et al., 1995) and also the extent of amphibole fractionation (e.g., Brophy, 2008). Ba/Th is a function of slab-derived fluid contribution to the source of magmas. Th/La is related to the amount of subducted sediments involved in magma generation (e.g., Elliott et al., 1997; Pearce et al., 1995; Plank, 2005).

$(\mathrm{Nb} / \mathrm{Y})_{N}$ and $(\mathrm{La} / \mathrm{Yb})_{N}$ ratios in glasses $(N$ denotes values normalized to primitive mantle following McDonough and Sun, 1995) reflect source enrichment in highly incompatible elements $(\mathrm{La}, \mathrm{Nb})$ relative to less incompatible elements (Yb, Y) (Pearce et al., 1995, 1984). These ratios are also strongly influenced by amphibole crystallization in evolved magmas, which are an important host for heavy REE and Y but not for La and Nb (Brophy, 2008). Tephra glasses from frontal Kamchatka volcanoes have relatively low $(\mathrm{Nb} / \mathrm{Y})_{N}<1.3$ and $(\mathrm{La} / \mathrm{Yb})_{N}<5$. This is a distinctive compositional feature of VF tephra in comparison to glass compositions from the other volcanic zones in Kamchatka. RA glasses have $(\mathrm{Nb} / \mathrm{Y})_{N}=1.1-3.6$ and $(\mathrm{La} / \mathrm{Yb})_{N}=3.1-10.9$. Glasses from the SR tephra have even higher $(\mathrm{Nb} / \mathrm{Y})_{N}>4.5$ and $(\mathrm{La} / \mathrm{Yb})_{N}=5.5-11.8$, mostly overlapping with RA compositions. Both ratios increase with increasing distance from the deep-sea trench. CKD glasses have $(\mathrm{Nb} / \mathrm{Y})_{N}$ similar to those in RA glasses and $(\mathrm{La} / \mathrm{Yb})_{N}>3$ overlapping with RA and SR glasses.

$(\mathrm{Ba} / \mathrm{Th})_{N}$ and $(\mathrm{Th} / \mathrm{La})_{N}$ ratios are indicative of magma source composition and related, respectively, to contributions from slab fluid and sediment melts in source of magmas (e.g., Elliott et al., 1997; Pearce et al., 1995; Plank, 2005). Both ratios exhibit significant variations along the volcanic arc and range from mantle-like values $\sim 1$ up to $4-6$ times higher than in primitive mantle. On a regional scale, VF tephras tend to have higher $(\mathrm{Ba} / \mathrm{Th})_{N}$ and lower $(\mathrm{Th} / \mathrm{La})_{N}$ than RA tephra: $(\mathrm{Ba} / \mathrm{Th})_{N}=1.5-6.2$ and $1.2-3.3,(\mathrm{Th} / \mathrm{La})_{N}=0.8-$ 2.7 and 1.0-4.4 in VF and RA, respectively). At a given distance along the volcanic arc, VF tephras always have higher $(\mathrm{Ba} / \mathrm{Th})_{N}$ and lower $(\mathrm{Th} / \mathrm{La})_{N}$ in comparison with RA tephras. SR tephra have a relatively low $(\mathrm{Ba} / \mathrm{Th})_{N}<2$ and high $(\mathrm{Th} / \mathrm{La})_{N}>2$ in the range of RA tephra. CKD tephra has ratios similar to VF tephra. 
To sum up the overview of geochemical data, compositions of glass in Kamchatka tephra are very variable, enabling robust correlation of tephra layers as well as identification of source volcano and volcanic zone, from which unknown tephra could come from.

\subsection{Using composition of glasses for fingerprinting ash layers in Kamchatka}

TephraKam was initially created for tephrochronological needs to enable reliable identification and dating of tephra layers in Kamchatka and neighboring areas and for identification of their sources. The data have been used in a number of publications (Cook et al., 2018; Derkachev et al., 2019; Plunkett et al., 2015; Ponomareva et al., 2018, 2013a, b, 2017, 2015b; Zelenin et al., 2020). Our experience showed that ash layers produced by the largest explosive eruptions in Kamchatka can be recognized using major element systematics of tephra glasses. A diagram of $\mathrm{SiO}_{2}$ vs. $\mathrm{K}_{2} \mathrm{O}$ is useful for primary identification (Fig. 3) because it utilizes elements of contrasting geochemical properties, reflecting mantle or crustal source enrichment in incompatible elements $\left(\mathrm{K}_{2} \mathrm{O}\right)$ and the extent of magma fractionation $\left(\mathrm{SiO}_{2}\right)$. In this respect, the diagram is more informative compared to other diagrams widely used in tephrochronology such as $\mathrm{FeO}$ vs. $\mathrm{CaO}$ or $\mathrm{FeO}$ vs. $\mathrm{TiO}_{2}$, utilizing elements whose concentrations are largely controlled by crystallization processes and strongly correlate with each other. More detailed discrimination of ash layers requires additional geochemical constraints. For example, low- $\mathrm{K}_{2} \mathrm{O}$ tephra glasses from Ksudach and Avachinsky volcanoes are well distinguished using $\mathrm{CaO}$ vs. $\mathrm{SiO}_{2}$ systematics; medium- $\mathrm{K}_{2} \mathrm{O}$ glass from Bezymianny volcano tephra has lower $\mathrm{Na}_{2} \mathrm{O}$ compared to Shiveluch glasses; high- $\mathrm{K}_{2} \mathrm{O}$ glass from Ushkovsky tephra has distinctively higher $\mathrm{P}_{2} \mathrm{O}_{5}$ compared to glass from high- $\mathrm{K}_{2} \mathrm{O}$ basaltic tephra SH\#28 from Shiveluch (Ponomareva et al., 2017).

In rare cases, tephra glasses from different volcanoes have hardly distinguishable major element composition. In this case minor elements determined by EPMA $(\mathrm{P}, \mathrm{Cl})$ and trace elements by LA-ICP-MS are useful to identify source volcanoes. In Fig. 5, we illustrate this case using compositions of tephra glasses from the Baranii Amphitheater Crater at the foot of Opala volcano (eruption OP 1356 BP) and Khangar volcano (eruption KHG6600 7490 BP). Although these tephras have very different ages, this comparison is instructive to illustrate the value of minor and trace element data to distinguish compositionally similar tephras. The difference in major elements is very subtle and mostly within long-term analytical uncertainty: Khangar glass has about $0.5 \mathrm{wt} \%$ lower $\mathrm{Al}_{2} \mathrm{O}_{3} ; \leq 0.2 \mathrm{wt} \%$ higher $\mathrm{CaO} ; \leq 0.5 \mathrm{wt} \%$ higher $\mathrm{K}_{2} \mathrm{O}$ at given $\mathrm{SiO}_{2}$; and otherwise completely overlapping $\mathrm{TiO}_{2}, \mathrm{FeO}, \mathrm{CaO}$, and $\mathrm{Na}_{2} \mathrm{O}$ contents (Fig. 5a-c). The two tephras, however, have clearly different $\mathrm{Cl}$ content (Fig. 5d) and very different shapes of normalized trace element patterns (Fig. 5e), enabling clear discrimination be-
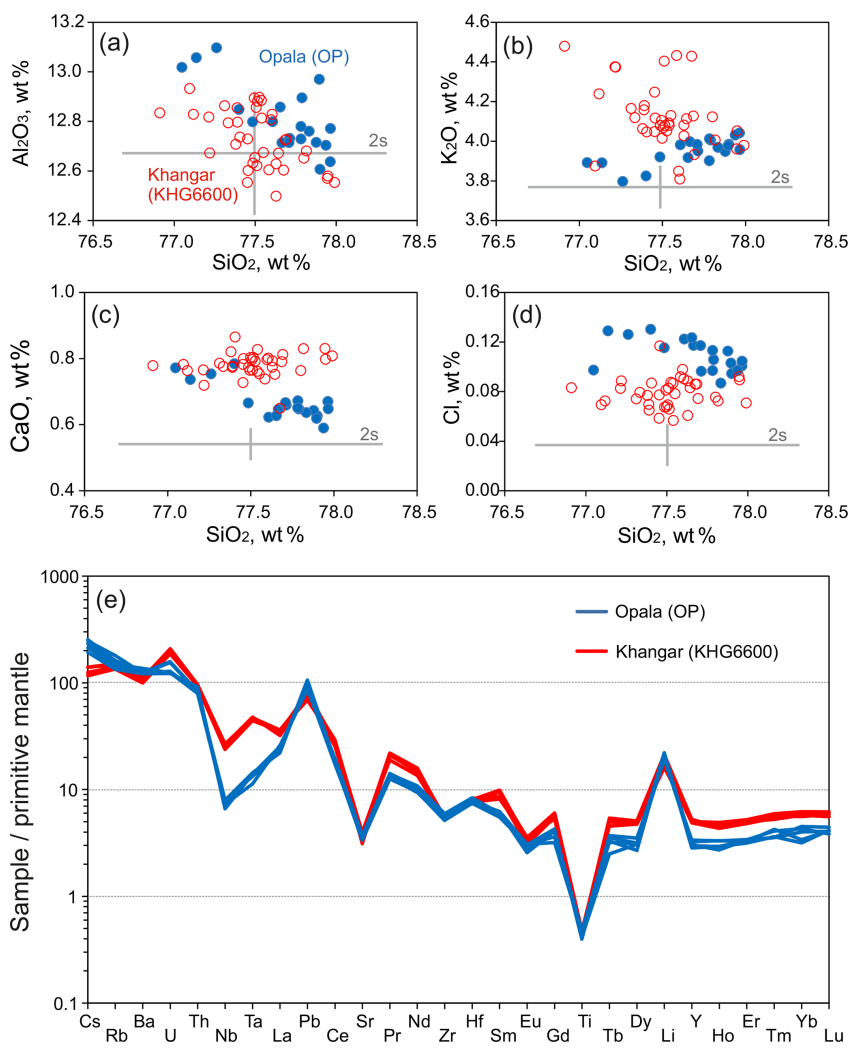

Figure 5. Example of using minor and trace element data to precisely identify source volcanoes for glasses with very similar major element composition: the case of tephras from Opala (eruption OP) and Khangar (KHG6600) volcanic centers. Uncertainty of single EPM points (a-d) corresponds to 2 standard deviation ( $2 \mathrm{~s})$ as calculated for average KHG6600 composition using TephraKam Table 1c. In (e) trace elements are normalized to primitive mantle composition (McDonough and Sun, 1995).

tween source volcanoes. Summarizing our experience to date, all tephras from different volcanic sources in Kamchatka have characteristic and unique chemical compositions.

Distinguishing tephra layers from the same volcano is a more difficult task. However, there is a number of examples from Kamchatkan volcanoes where tephra compositions are different even over short intervals of time (e.g., Kyle et al., 2011; Ponomareva et al., 2013b, 2017, 2015b). For example, Ponomareva et al. (2015b) showed that even compositionally similar tephra layers of the frequently erupting Shiveluch volcano can be distinguished using major element systematics in tephra glasses, particularly when the time period of eruption can be narrowed using marker layers from other volcanoes. The cases of compositionally identical products of different eruptions from the same volcanic center are also known. For example, Derkachev et al. (2020) reported two late Pleistocene layers produced by large eruptions from Gorely caldera, which have barely distinguishable major and trace element composition of glass. On a longer timescale of 


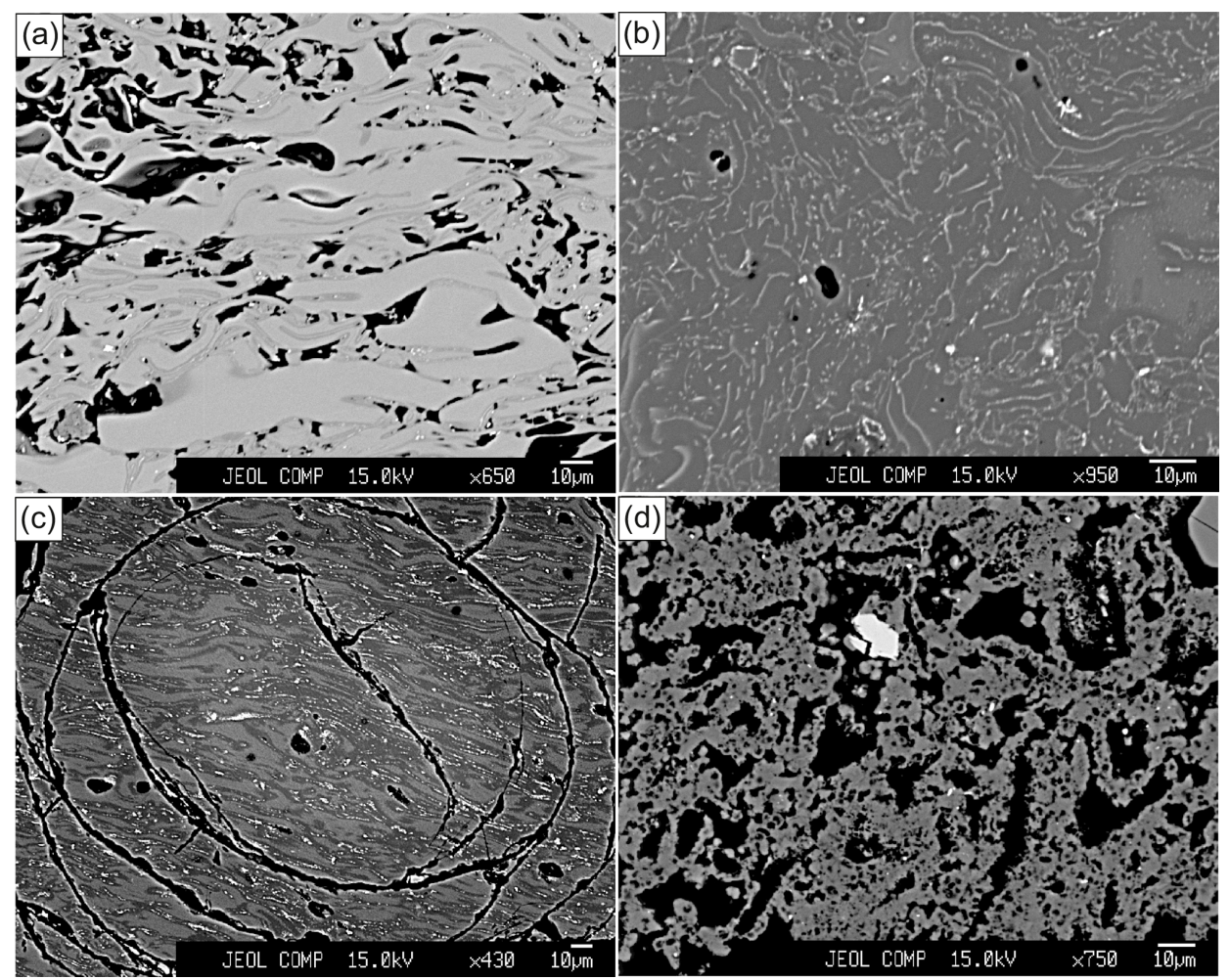

Figure 6. Backscattered electron images of glass devitrification in welded tuffs: (a) slight alteration along welded glass particles (Sample 198-75, Karymsky/Stena-Sobolinaya caldera); (b) more advanced alteration, precipitation of magnetite (sample 169-75, Karymsky/StenaSobolinaya caldera); (c) strong devitrification, developed perlite texture (sample 1989L-97b, unknown source, Alney-Chashakondzha); and (d) complete devitrification (sample PAU-8; Pauzhetka caldera, no glass preserved).

100000 years, the products of the Gorely caldera eruptions are more variable (Seligman et al., 2014), enabling their identification using glass composition in tephra and welded tuffs.

\subsection{Effects of alteration on major and trace elements in glass from welded tuffs}

TephraKam contains abundant data for glasses in welded tuffs of the Miocene to Pleistocene from different parts of Kamchatka. These rocks clearly represent products of large caldera-forming eruptions during the history of Kamchatka. Identification of their sources, age, and ash distribution is of great interest. However, some welded tuff glasses in the database have signs of secondary alteration that hamper their direct interpretation as compositions representative for native glass, i.e., quenched melt. Typically, the alteration results in characteristic "spaghetti"-like textures, precipitates of tiny magnetite crystals in glassy matrix followed by complete glass replacement by microcrystalline aggregate, and development of concentric perlite texture (Fig. 6). The process of devitrification is also associated with chemical modification of welded tuffs. Spot analyses usually reveal a large and correlated variability of alkalis and alkali earth elements within single samples, which typically is not observed in volcanic glasses from pumice fragments or ash layers. Representative trace element composition of variably altered glasses from the same unit of Karymsky/Stena-Sobolinaya caldera welded tuffs is shown in Fig. 7. A major feature of the glass alteration is enrichment in $\mathrm{K}_{2} \mathrm{O}, \mathrm{Rb}$, and $\mathrm{Li}$ (all are monovalent alkaline elements) that is inversely correlated with depletion in $\mathrm{Na}_{2} \mathrm{O}, \mathrm{CaO}$, and $\mathrm{Sr}$. Elements $\mathrm{Ba}, \mathrm{U}, \mathrm{Th}, \mathrm{Pb}, \mathrm{Nb}, \mathrm{Ta}, \mathrm{Zr}, \mathrm{Hf}$, $\mathrm{Ti}, \mathrm{P}$, and $\mathrm{Y}$ and REEs exhibit small variability and are relatively immobile during alteration. Concentrations of the immobile elements are informative of the initial concentrations in glass and can be used for correlations between different ignimbrite units and with pristine tephra glasses. An example of geochemical fingerprinting of completely devitrified samples from Pauzhetka caldera in southern Kamchatka is provided by Ponomareva et al. (2018). These authors noted that elements $\mathrm{B}, \mathrm{Ba}, \mathrm{Eu}$, and $\mathrm{V}$ also reveal mobility in strongly altered tuffs and should be interpreted with caution.

\subsection{Discrimination of glasses from different volcanic zones in Kamchatka using immobile trace elements}

In comparison with major elements, concentrations of some trace elements in Kamchatka glasses are more variable and exhibit characteristic regional distribution (Fig. 4). This 
(a)
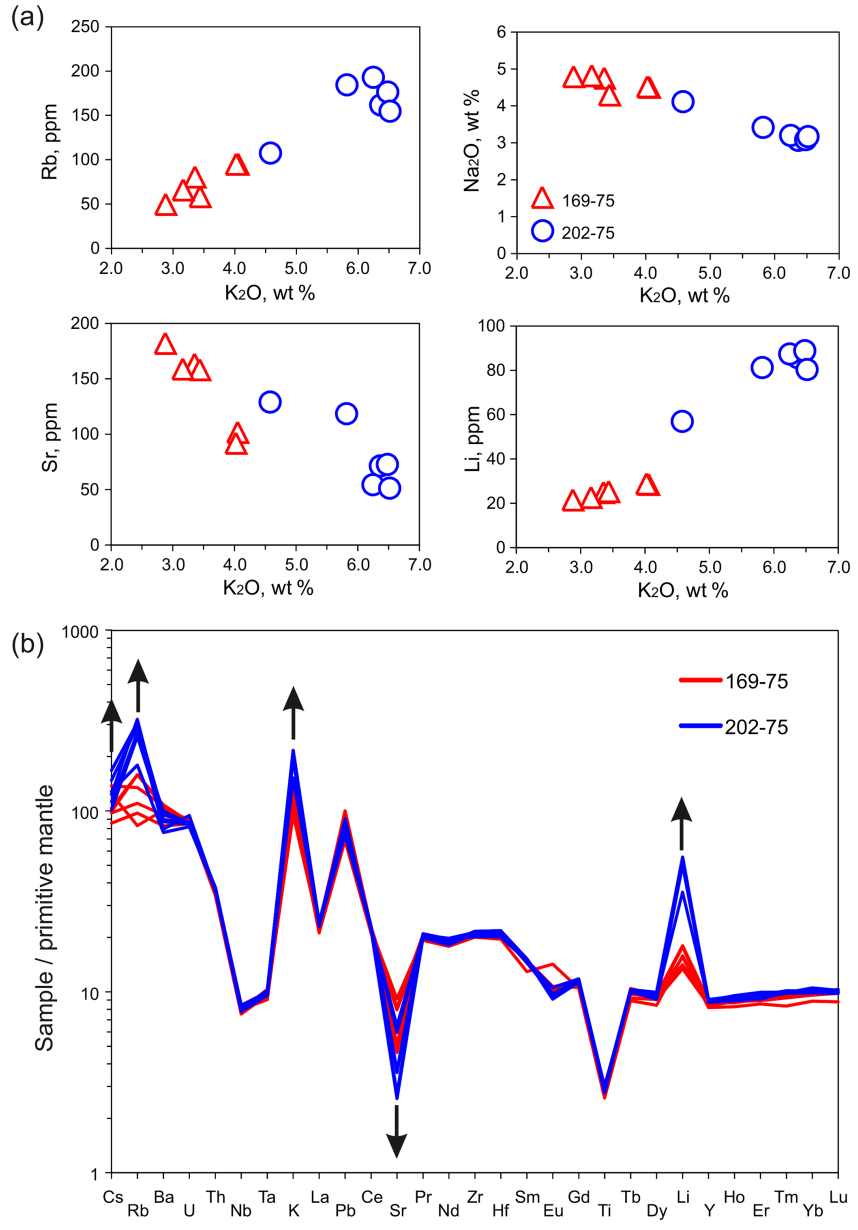

Figure 7. Illustration of chemical effects of secondary alteration on major and trace element composition of glass from welded tuffs: (a) covariations in mobile elements and (b) trace elements normalized to primitive mantle composition (McDonough and Sun, 1995). Arrows denote effect of alteration. Samples 169-75 (less altered) and 202-75 (more altered) are from the Stena-Sobolinaya caldera and likely belong to the same unit, judging from their very close concentrations of immobile elements.

makes it possible to use trace elements for identification of volcanic zones, i.e., sources of distal tephra. Ideally, these criteria should use immobile elements, which are unaffected by alteration of glasses in welded tuffs and ancient tephras buried in marine sediments and other deposits. We performed a search for the most effective criteria based on trace element concentrations in glasses from this database. Based on this search, diagrams using trace element ratios $\mathrm{Nb} / \mathrm{Y}, \mathrm{Nb} / \mathrm{Y}$ and $\mathrm{Th} / \mathrm{Y}$ provide the most robust discrimination of glass compositions from different volcanic zones in Kamchatka (Fig. 8, TephraKam Table 2f). The fields of different volcanic zones are initially drawn using data on glasses from robustly identified sources of the Holocene and Late Pleistocene ages (Fig. 8a, b). Glasses from the volcanic front, rear arc, and the Sredinny Range form separate fields in these diagrams, which should be related to systematically changing conditions of magma generation with increasing distance from volcano to the deep-sea trench and subducting plate. Glasses from the Central Kamchatka Depression volcanoes largely overlap with rear-arc glasses and partly overlap with volcanic front samples, which is in agreement with the geodynamic position of CKD (Fig. 1). Figure 8c and d show that glasses of the middle and early Pleistocene have compositions falling closely within the corresponding fields of different volcanic zones. Although $\mathrm{Th} / \mathrm{Y}$ and $\mathrm{La} / \mathrm{Y}$ are somewhat scattered at given $\mathrm{Nb} / \mathrm{Y}$, the volcanic zones can still be precisely identified in most cases. This consistency of compositions suggests that Kamchatka has not been affected by major tectonic reorganization, at least during Pleistocene and Holocene (ca. $2.5 \mathrm{Ma}$ ), and the present position of ancient volcanic centers corresponds closely to their initial position. Older MiocenePliocene samples are relatively rare in this database (Fig. 8ef). However, we notice that glasses in Neogene rocks from the Sredinny Range have distinctive compositions that plot outside the range of Pleistocene-Holocene SR compositions and are more similar to modern rear arc and volcanic front samples. This might indicate that conditions of magma generation under Sredinny Range during the Pliocene were more similar to the present-day volcanic front and rear arc and that Sredinny Range volcanoes were located closer to the deepsea trench and subducting plate at that time. This conclusion is in agreement with the proposed major tectonic reorganization in Kamchatka in the Neogene and shifting of volcanic front from the Sredinny Range to its present position in eastern Kamchatka (Avdeiko et al., 2007; Lander and Shapiro, 2007; Legler, 1977; Volynets, 1994). Thus, the diagrams in Fig. 8 can be successfully used to identify tephra erupted from different volcanic zones during the Holocene and Pleistocene. The proposed criteria are likely not valid for the Neogene, when the Kamchatka subduction zone had a different configuration. The diagrams can be particularly useful for identifying the provenance of distal tephras in marine sediments offshore of Kamchatka, for analysis of synchronicity of activity in different zones, and for analysis of temporal geochemical variability of volcanism.

\section{Data availability}

The archive .zip file containing tables of this database is available on ResearchGate: https://doi.org/10.13140/RG.2.2.23627.13606 (Portnyagin et al., 2019). Updates will be available under the same web address or can be requested directly from the first two authors of this paper. A web-based version of this database will be released in the near future. 

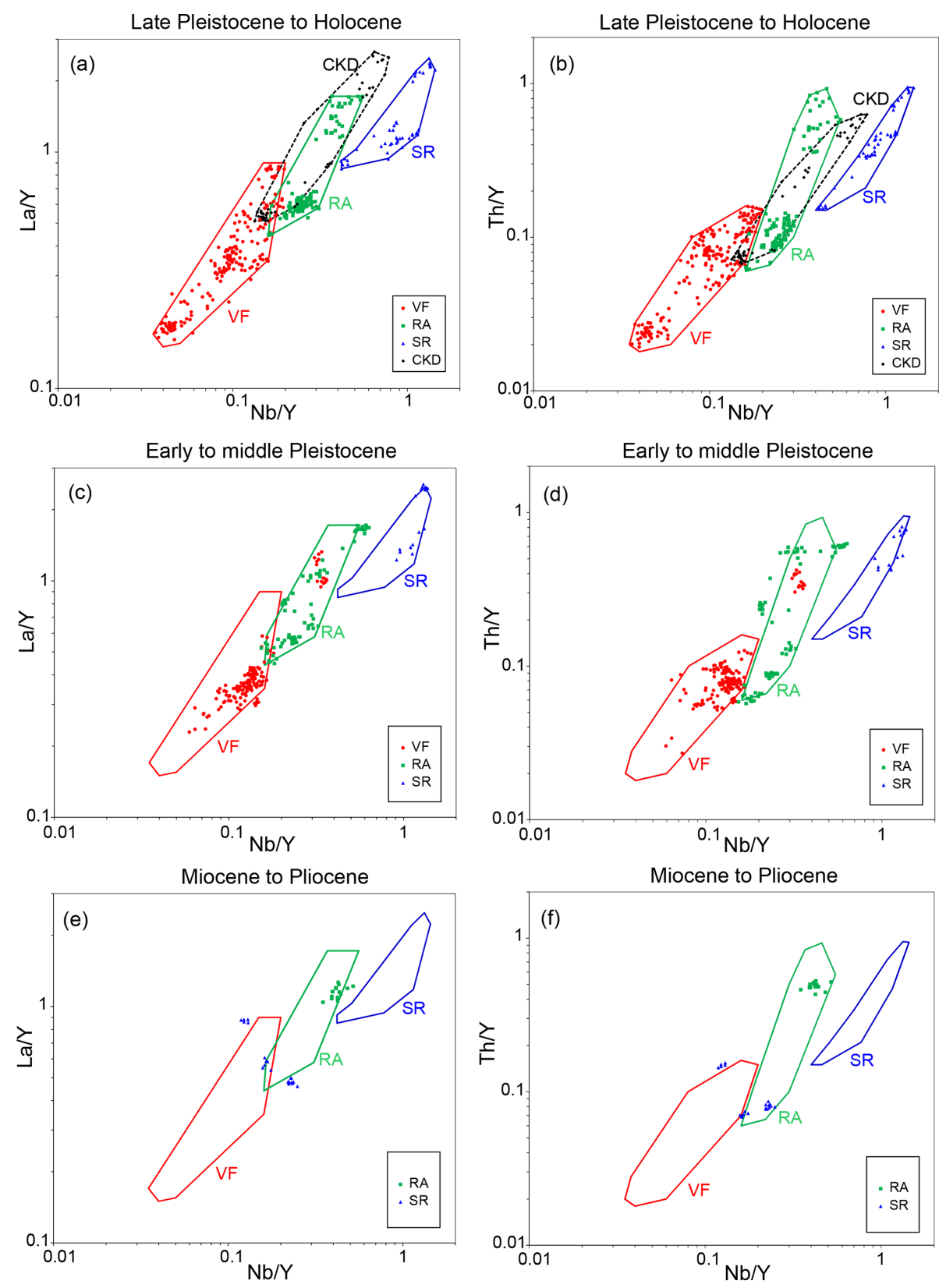

Figure 8. Discrimination diagrams for different volcanic zones in Kamchatka. The fields are drawn based on Holocene and late Pleistocene compositions. Colored symbols show compositions of glasses according to their estimated ages and present-day location: Holocene and late Pleistocene (a, b), early to middle Pleistocene (c-d), and Miocene-Pliocene (e-f).

\section{Conclusions}

TephraKam is the largest and most comprehensive collection of internally consistent high-quality chemical analyses of major and trace elements in glasses of pyroclastic rocks of Kamchatka volcanoes. Precise or estimated ages are provided for every sample. Use of this database opens the possibility for reliable identification and correlation of tephra layers in Kamchatka and neighboring areas, enables dating of sedimentary archives onshore and offshore of Kam- chatka and allows the multicomponent petrological and geochemical analysis of composition and origin of magmatic melts, preserved as quenched glass in tephra. The latter application is straightforward for rhyolite glasses, which have been shown to preserve the composition of magmas at depth (except for volatiles) and thus are informative of magma composition and its storage conditions at depth in Kamchatka (Ponomareva et al., 2015a). The amount of presented data is comparable and exceeds that available from published sources on the composition of volcanic rocks in Kam- 
chatka (e.g., GEOROC database). For silicic compositions, this database is a major source of information.

Author contributions. MVP and VVP designed the study and wrote the paper. MVP, VVP, LIB, MMP, and ANR conducted the fieldwork and collected most of the samples. MVP developed protocols of the EPM and LA-ICP-MS analyses and designed the database structure. MVP, VVP, AAP, and ANR produced the EPM and LA-ICP-MS data. EAZ compiled all the age data. DGS managed the LA-ICP-MS analyses. All authors discussed the results and participated in preparation of the paper.

Competing interests. The authors declare that they have no conflict of interest.

Acknowledgements. The authors cordially thank all colleagues who donated their samples for this research. The field efforts of Ilya N. Bindeman, Tatiana G. Churikova, Oleg V. Dirksen, Natalia V. Gorbach, Boris N. Gordeichik, Sergei A. Khubunaya, Natalia A. Kim, Stepan P. Krasheninnikov, Philip R. Kyle, Ivan V. Melekestsev, Nikita L. Mironov, Alexander B. Perepelov, Peter Rinkleff, and Oleg B. Seliangin are highly appreciated. We are deeply grateful to the late Olga A. Braitseva and Vladimir L. Leonov for providing their samples and for their long-term support of our research. We appreciate the help of Kronotsky Reserve in acquiring the samples from Uzon caldera and Kronotsky Lake. We thank Mario Thöner and Ulrike Westernströer for all their efforts in managing laboratory work and many years of excellent assistance with the electron probe and LA-ICP-MS. Constructive comments from Bärbel Sarbas and an anonymous referee helped us to improve the quality of this paper.

Financial support. This research was supported by the Russian Science Foundation (grant no. 16-17-10035, partial funding of fieldwork, data processing, and work on the database and manuscript). All laboratory costs related to electron microprobe and LA-ICPMS analyses were covered by the GEOMAR Helmholtz Centre for Ocean Research (Kiel, Germany).

Review statement. This paper was edited by Attila Demény and reviewed by Bärbel Sarbas and one anonymous referee.

\section{References}

Auer, S. L., Bindeman, I., Wallace, P., Ponomareva, V. V., and Portnyagin, M.: The Origin of Hydrous, high- $\delta^{18} \mathrm{O}$ voluminous volcanism: Diverse Oxygen Isotope Values and High Magmatic Water Contents within the Volcanic Record of Klyuchevskoy Volcano, Kamchatka, Russia, Contrib. Mineral. Petrol., 157, 209230, https://doi.org/10.1007/s00410-008-0330-0, 2009.

Avdeiko, G. P., Saveleyv, D. P., Palueva, A. A., and Popruzhenko, S. V.: Evolution of the Kurile-Kamchatkan Volcanic Arcs and Dynamics of the Kamchatka-Aleutian Junction, in: Volcanism and
Subduction: The Kamchatka Region, edited by: Eichelberger, J., Gordeev, E., Kasahara, M., Izbekov, P., and Lees, J., American Geophysical Union, Washington DC, 2007.

Bachmann, O. and Bergantz, G. W.: Rhyoilites and their source mushes across tectonic settings, J. Petrol., 49, 2277-2285, https://doi.org/10.1093/petrology/egn2068, 2008.

Bazanova, L. I. and Pevzner, M. M.: Khangar: One more active volcano in Kamchatka, Dokl. Earth Sci., 377A, 307-310, 2001.

Bazanova, L. I., Braitseva, O. A., Dirksen, O. V., Sulerzhitskii, L. D., and Danhara, T.: Ashfalls due to great Holocene eruptions along the Ust-Bolcheretsk-Petropavlovsk-Kamchatskii geotraverse: sources, chronology, rate of occurrence, Volcanol. Seismol., 6, 30-46, 2005.

Bazanova, L. I., Ponomareva, V. V., Portnyagin, M. V., and Perepelov, A. B.: Age and scale of the largest explosive eruptions in the Paltsevskaia caldera area (eastern Kamchatka), in: Volcanism and Related Processes: Proceedings of the XXII All-Russian Scientific Conference on Volcanologist's Day, 28-29 March, IVS FEB RAS, Petropavlovsk-Kamchatsky, 2019.

Bindeman, I. N., Leonov, V. L., Izbekov, P. E., Ponomareva, V. V., Watts, K. E., Perepelov, A. B., Bazanova, L. I., Singer, B. S., Jicha, B., Schmitt, A. K., Portnyagin, M. V., and Chen, C. H.: Large-volume silicic volcanism in Kamchatka: Ar-Ar and U$\mathrm{Pb}$ ages, isotopic, and geochemical characteristics of major preHolocene caldera-forming eruptions, J. Volcanol. Geoth. Res., 189, 57-80, https://doi.org/10.1016/j.jvolgeores.2009.10.009, 2010.

Bindeman, I. N., Leonov, V. L., Colón, D. P., Rogozin, A. N., Shipley, N., Jicha, B., Loewen, M. W., and Gerya, T. V.: Isotopic and Petrologic Investigation, and a Thermomechanical Model of Genesis of Large-Volume Rhyolites in Arc Environments: Karymshina Volcanic Complex, Kamchatka, Russia, Front. Earth Sci., 6, https://doi.org/10.3389/feart.2018.00238, 2019.

Braitseva, O. A., Melekestsev, I. V., Bogoyavlenskaya, G. E., and Maksimov, A. P.: Bezymianny volcano: eruptive history and activity dynamics, Volcanol. Seismol., 12, 165-194, 1991.

Braitseva, O. A., Melekestsev, I. V., Ponomareva, V. V., and Sulerzhitsky, L. D.: The ages of calderas, large explosive craters and active volcanoes in the Kuril-Kamchatka region, B. Volcanol., 57, 383-402, 1995.

Braitseva, O. A., Melekestsev, I. V., Ponomareva, V. V., and Kirianov, V. Y.: The caldera-forming eruption of Ksudach volcano about cal. AD 240, the greatest explosive event of our era in Kamchatka, J. Volcanol. Geoth. Res., 70, 49-66, 1996.

Braitseva, O. A., Ponomareva, V. V., Sulerzhitsky, L. D., Melekestsev, I. V., and Bailey, J.: Holocene key-marker tephra layers in Kamchatka, Russia, Quaternary Res., 47, 125-139, 1997.

Braitseva, O. A., Bazanova, L. I., Melekestsev, I. V., and Sulerzhitsky, L. D.: Largest Holocene eruptions of Avachinsky volcano, Kamchatka, Volcanol. Seismol., 20, 1-27, 1998.

Brophy, J.: A study of rare earth element (REE)-SiO $\mathrm{Si}_{2}$ variations in felsic liquids generated by basalt fractionation and amphibolite melting: a potential test for discriminating between the two different processes, Contrib. Mineral. Petrol., 156, 337-357, https://doi.org/10.1007/s00410-008-0289-x, 2008.

Cashman, K. V. and Edmonds, M.: Mafic glass compositions: a record of magma storage conditions, mixing and ascent, Philos. T. R. Soc., A377, 20180004, https://doi.org/10.1098/rsta.2018.0004, 2019. 
Churikova, T., Dorendorf, F., and Worner, G.: Sources and fluids in the mantle wedge below Kamchatka, evidence from across-arc geochemical variation, J. Petrol., 42, 1567-1593, 2001.

Churikova, T. G., Gordeychik, B. N., Edwards, B., Ponomareva, V. V., and Zelenin, E.: The Tolbachik volcanic massif: a review of the petrology, volcanology and eruption history prior to the 2012-2013 eruption, J. Volcanol. Geoth. Res., 307, 3-21, 2015.

Clift, P. D., Chan, L.-H., Blusztajn, J., Layne, G. D., Kastner, M., and Kelly, R. K.: Pulsed subduction accretion and tectonic erosion reconstructed since $2.5 \mathrm{Ma}$ from the tephra record offshore Costa Rica, Geochem. Geophy. Geosy., 6, Q09016, https://doi.org/10.1029/2005GC000963, 2005.

Cook, E., Portnyagin, M., Ponomareva, V., Bazanova, L., Svensson, A., and Garbe-Schönberg, D.: First identification of cryptotephra from the Kamchatka Peninsula in a Greenland ice core: implications of a widespread marker deposit that links Greenland to the Pacific northwest, Quaternary Sci. Rev., 181, 200206, https://doi.org/10.1016/j.quascirev.2017.1011.1036, 2018.

Derkachev, A. N., Gorbarenko, S. A., Ponomareva, V. V., Portnyagin, M. V., Malakhova, G. I., and Yanguang, L.: Middle to late Pleistocene record of explosive volcanic eruptions in marine sediments offshore Kamchatka (Meiji Rise, NW Pacific), J. Quaternary Sci., 35, 362-379, https://doi.org/10.1002/jqs.3175, 2020.

Dirksen, O., van den Bogaard, C., Danhara, T., and Diekmann, B.: Tephrochronological investigation at Dvuh-yurtochnoe lake area, Kamchatka: Numerous landslides and lake tsunami, and their environmental impacts, Quatern. Int., 246, 298-311, 2011.

Dirksen, O. V.: Late Quaternary Areal Volcanism of Kamchatka, Dissertation of candidate of geographic sciences, Saint Petersburg State University 2009 (in Russian).

Dirksen, O. V. and Bazanova, L. I.: Late Quaternary Volcanism of the Sedankinsky Dol, Sredinny Range, Kamchatka, in: Volcanism and geodynamics. Proceedings of the IV All-Russian Symposium on Volcanology and Paleovolcanology, PetropavlovskKamchatsky, 22-27 September, Petropavlovsk-Kamchatsky, 1, 355-358, 2009 (in Russian).

Dirksen, O. V. and Melekestsev, I. V.: Chronology, evolution and morphology of plateau basalt eruptive centers in Avacha River area, Kamchatka, Russia, J. Volcanol. Seismol., 21, 1-27, 1999.

Duggen, S., Portnyagin, M., Baker, J., Ulfbeck, D., Hoernle, K., Garbe-Schönberg, D., and Grassineau, N.: Drastic shift in lava geochemistry in the volcanic-front to rear-arc region of the Southern Kamchatkan subduction zone: Evidence for the transition from slab surface dehydration to sediment melting, Geochim. Cosmochim. Ac., 71, 452-480, 2007.

Elliott, T., Plank, T., Zindler, A., White, W., and Bourdon, B.: Element transport from slab to volcanic front at the Mariana arc, J. Geophys. Res., 102, 14991-15019, 1997.

Farr, T. G., Rosen, P. A., Caro, E., Crippen, R., Duren, R., Hensley, S., Kobrick, M., Paller, M., Rodriguez, E., Roth, L., Seal, D., Shaffer, S., Shimada, J., Umland, J., Werner, M., Oskin, M., Burbank, D., and Alsdorf, D.: The Shuttle Radar Topography Mission, Rev. Geophys., 45, RG2004, https://doi.org/10.1029/2005RG000183, 2007.

Florensky, I. V.: On the age of Uzon and Krashenninnikov calderas, Volcanol. Seismol., 1, 102-106, 1984.

Froggatt, P. C.: Standardization of the chemical analysis of tephra deposits. Report of the ICCT Working Group, Quatern. Int., 1314, 93-96, 1992.
Frost, B. R., Barnes, C. G., Collins, W. J., Arculus, R. J., Ellis, D. J., and Frost, C. D.: A Geochemical Classification for Granitic Rocks, J. Petrol., 42, 2033-2048, 2001.

Fricker, M. B., Kutscher, D., Aeschlimann, B., Frommer, J., Dietiker, R., Bettmer, J., and Gunther, D.: High spatial resolution trace element analysis by LA-ICP-MS using a novel ablation cell for multiple or large samples, Int. J. Mass. Spectrom., 307, 3945, 2011.

Gill, J. B.: Orogenic andesites and plate tectonics, Springer-Verlag, Berlin-Heidelberg, 1981.

Gorbatov, A., Kostoglodov, V., Suarez, G., and Gordeev, E.: Seismicity and structure of the Kamchatka subduction zone, J. Geophys. Res., 102, 17833-17898, 1997.

Griffin, W., Powell, W., Pearson, N., and O'reilly, S.: GLITTER: data reduction software for laser ablation ICP-MS, Laser Ablation-ICP-MS in the earth sciences, Mineralogical association of Canada short course series, 40, 204-207, 2008.

Hughes, G. R. and Mahood, G. A.: Tectonic controls on the nature of large silicic calderas in volcanic arcs, Geology, 36, 627-630, 2008.

Hulse, E., Keeler, D., Zubrow, E., Korosec, G., Ponkratova, I., and Curtis, C.: Preliminary report on archaeological fieldwork in the Kamchatka region of Russia, Sibirica, Interdisciplinary Journal of Siberian Studies, 10, 48-74, 2011.

Hunt, J. B. and Hill, P. G.: An inter-laboratory comparison of the electron probe microanalysis of glass geochemistry, Quatern. Int., 34-36, 229-241, 1996.

Hunt, J. B. and Hill, P. G.: Tephrological implications of beam size-sample-size effects in electron microprobe analysis of glass shards, J. Quaternary Sci., 16, 105-117, 2001.

Jarosewich, E. J., Nelen, J. A., and Norberg, J. A.: Reference samples for electron microprobe analysis, Geostandard. Newslett., 4, 43-47, 1980.

Jochum, K. P., Stoll, B., Herwig, K., Willbold, M., Hofmann, A. W., Amini, M., Aarburg, S., Abouchami, W., Hellebrand, E., Mocek, B., Raczek, I., Stracke, A., Alard, O., Bouman, C., Becker, S., Dücking, M., Brätz, H., Klemd, R., de Bruin, D., Canil, D., Cornell, D., de Hoog, C.-J., Dalpé, C., Danyushevsky, L., Eisenhauer, A., Gao, Y., Snow, J. E., Groschopf, N., Günther, D., Latkoczy, C., Guillong, M., Hauri, E. H., Höfer, H. E., Lahaye, Y., Horz, K., Jacob, D. E., Kasemann, S. A., Kent, A. J. R., Ludwig, T., Zack, T., Mason, P. R. D., Meixner, A., Rosner, M., Misawa, K., Nash, B. P., Pfänder, J., Premo, W. R., Sun, W. D., Tiepolo, M., Vannucci, R., Vennemann, T., Wayne, D., and Woodhead, J. D.: MPI-DING reference glasses for in situ microanalysis: New reference values for element concentrations and isotope ratios, Geochem. Geophy. Geosy., 7, Q02008, https://doi.org/10.1029/2005GC001060, 2006.

Jochum, K. P., Weis, U., Stoll, B., Kuzmin, D., Yang, Q. C., Raczek, I., Jacob, D. E., Stracke, A., Birbaum, K., Frick, D. A., Gunther, D., and Enzweiler, J.: Determination of Reference Values for NIST SRM 610-617 Glasses Following ISO Guidelines, Geostand. Geoanal. Res., 35, 397-429, 2011.

Kimura, J.-I. and Chang, Q.: Origin of the suppressed matrix effect for improved analytical performance in determination of major and trace elements in anhydrous silicate samples using $200 \mathrm{~nm}$ femtosecond laser ablation sector-field inductively coupled plasma mass spectrometry, J. Anal. Atom. Spectrom., 27, 1549-1559, https://doi.org/10.1039/C1542JA10344C, 2012. 
Kimura, J.-I., Nagahashi, Y., Satoguchi, Y., and Chang, Q.: Origins of felsic magmas in Japanese subduction zone: Geochemical characterizations of tephra from caldera-forming eruptions <5 Ma, Geochem. Geophy. Geosy., 16, 2147-2174, https://doi.org/10.1002/2015GC005854, 2015.

Kozhurin, A., Acocella, V., Kyle, P., Lagmay, A. M., Melekestsev, I. V., Ponomareva, V., Rust, D., Tibaldi, A., Tunesi, A., Corazzato, C., Rovida, A., Sakharov, A., Tengonciang, A., and Uy, H.: Trenching studies of active faults in Kamchatka, eastern Russia: Palaeoseismic, tectonic and hazard implications, Tectonophysics, 417, 285-304, 2006.

Kozhurin, A. I., Pinegina, T. K., Ponomareva, V. V., Zelenin, E. A., and Mikhailyukova, P. G.: Rate of collisional deformation in Kamchatsky Peninsula, Kamchatka, Geotectonics, 48, 122-138, 2014.

Kuehn, S. C., Froese, D. G., and Shane, P. A. R.: The INTAV intercomparison of electron-beam microanalysis of glass by tephrochronology laboratories: Results and recommendations, Quatern. Int., 246, 19-47, 2011.

Kutterolf, S., Freundt, A., and Peréz, W.: Pacific offshore record of plinian arc volcanism in Central America: 2. Tephra volumes and erupted masses, Geochem. Geophy. Geosy., 9, Q02S02, https://doi.org/10.1029/2007GC001791, 2008.

Kyle, P. R., Ponomareva, V. V., and Schluep, R. R.: Geochemical characterization of marker tephra layers from major Holocene eruptions, Kamchatka Peninsula, Russia, Int. Geol. Rev., 53, 1059-1097, https://doi.org/10.1080/00206810903442162, 2011.

Lander, A. V. and Shapiro, M. N.: The origin of the modern Kamchatka subduction zone, in: Volcanism and Subduction: The Kamchatka Region, edited by: Eichelberger, J., Gordeev, E., Kasahara, M., Izbekov, P., and Lees, J., American Geophysical Union, Washington DC, 2007.

Legler, V. A.: Evolution of Kamchatka from plate tectonic theory (sources of energy for tectinc processes and plate dynamics), in: Tectonics of the lithosphere plates, Inst. of oceanology, Acad. Sci. USSR, Moscow, 1977 (in Russian).

Le Maitre, R. W., Streckeisen, A., Zanetti, B., Le Bas, M. J., Bonin, B., Bateman, P., Bellieni, G., Dudek, A., Efremova, S., Keller, J., Lameyre, J., Sabine, P. A., Schmid, R., Soerensen, H., and Wooley, A. R. (Eds.): Igneous rocks. A classification and glossary of terms, Cambridge University Press, 2002.

Liu, Y., Hu, Z., Gao, S., Günther, D., Xu, J., Gao, C., and Chen, H.: In situ analysis of major and trace elements of anhydrous minerals by LA-ICP-MS without applying an internal standard, Chem. Geol., 257, 34-43, 2008.

Longerich, H. P., Jackson, S. E., and Gunther, D.: Laser ablation inductively coupled plasma mass spectrometric transient signal data acquisition and analyte concentration calculation, J. Anal. Atom. Spectrom., 11, 899-904, 1996.

Lowe, D. J.: Tephrochronology and its application: A review, Quat. Geochronol., 6, 107-153, 2011.

Lowe, D. J., Pearce, N. J. G., Jorgensen, M. A., Kuehn, S. C., Tryon, C. A., and Hayward, C. L.: Correlating tephras and cryptotephras using glass compositional analyses and numerical and statistical methods: Review and evaluation, Quaternary Sci. Rev., 175, 144, 2017.

Mackay, H., Hughes, P. D., Jensen, B. J., Langdon, P. G., PyneO'Donnell, S. D., Plunkett, G., Froese, D. G., Coulter, S., and Gardner, J. E.: A mid to late Holocene cryptotephra framework from eastern North America, Quaternary Sci. Rev., 132, 101113, https://doi.org/10.1016/j.quascirev.2015.11.011, 2016.

Maruyama, S., Hattori, K., Hirata, T., and Danhara, T.: A proposed methodology for analyses of wide-ranged elements in volcanic glass shards in widespread Quaternary tephras, Quatern. Int., 397, 267-280, 2016.

Masurenkov, Y. P. (Ed.): Volcanic Center, structure, dynamics, and erupted material (Karymsky structure), Nauka Press Moscow, 1980.

McDonough, W. F. and Sun, S. S.: The Composition of the Earth, Chem. Geol., 120, 223-253, 1995.

Melekestsev, I. V., Litasova, S. N., and Sulerzhitsky, L. D.: On the age and scale of the directed-blast catastrophic eruption of the Avachinsky volcano (Kamchatka) in the Late Pleistocene, Volcanol. Seismol., 13, 135-146, 1992.

Melekestsev, I. V., Ponomareva, V. V., and Volynets, O. N.: Kizimen volcano, Kamchatka - A future Mount St. Helens?, J. Volcanol. Geoth. Res., 65, 205-226, https://doi.org/10.1016/03770273(94)00082-R, 1995.

Morgan, G. B. and London, D.: Optimizing the electron microprobe analysis of hydrous alkali aluminosilicate glasses, Am. Mineral., 81, 1176-1185, 1996.

Morgan, G. B. and London, D.: Effect of current density on the electron microprobe analysis of alkali aluminosilicate glasses, Am. Mineral., 90, 1131-1138, 2005.

Mosbah, M., Metrich, N., and Massiot, P.: PIGME fluorine determination using a nuclear microprobe with application to glass inclusions, Nucl. Instrum. Meth. B, 58, 227-231, 1991.

Nielsen, C. H. and Sigurdsson, H.: Quantitative methods for electron microprobe analysis of sodium in natural and synthetic glasses, Am. Mineral., 66, 547-552, 1981.

Pearce, J.: Sources and settings of granitic rocks, Episodes, 19, 120 125, 1996

Pearce, J. A., Harris, N. B. W., and Tindle, A. G.: Trace-Element Discrimination Diagrams for the Tectonic Interpretation of Granitic-Rocks, J. Petrol., 25, 956-983, 1984.

Pearce, J. A., Baker, P. E., Harvey, P. K., and Luff, I. W.: Geochemical Evidence for Subduction Fluxes, Mantle Melting and Fractional Crystallization Beneath the South Sandwich Island Arc, J. Petrol., 36, 1073-1109, 1995.

Pearce, N. J., Westgate, J. A., and Perkins, W. T.: Developments in the analysis of volcanic glass shards by laser ablation ICP-MS: quantitative and single internal standard-multielement methods, Quatern. Int., 34, 213-227, 1996.

Pearce, N. J. G.: Towards a protocol for the trace element analysis of glass from rhyolitic shards in tephra deposits by laser ablation ICP-MS, J. Quaternary Sci., 29, 627-640, 2014.

Pearce, N. J. G., Denton, J. S., Perkins, W. T., Westgate, J. A., and Alloway, B. V.: Correlation and characterisation of individual glass shards from tephra deposits using trace element laser ablation ICP-MS analyses: current status and future potential, J. Quaternary Sci., 22, 721-736, 2007.

Peccerillo, A. and Taylor, S. R.: Geochemistry of eocene calcalkaline volcanic rocks from the Kastamonu area, Northern Turkey, Contrib. Mineral. Petrol., 58, 63-81, 1976.

Pendea, I. F., Harmsen, H., Keeler, D., Zubrow, E. B., Korosec, G., Ruhl, E., Ponkratova, I., and Hulse, E.: Prehistoric human responses to volcanic tephra fall events in the Ust-Kamchatsk region, Kamchatka Peninsula (Kam- 
chatsky Krai, Russian Federation) during the middle to late Holocene (6000-500 cal BP), Quatern. Int., 394, 51-68, https://doi.org/10.1016/j.quaint.2015.07.033, 2016.

Pettke, T., Halter, W. E., Webster, J. D., Aigner-Torres, M., and Heinrich, C. A.: Accurate quantification of melt inclusion chemistry by LA-ICPMS: a comparison with EMP and SIMS and advantages and possible limitations of these methods, Lithos, 78, 333-361, 2004.

Pevzner, M. M.: The northern boundary of volcanic activity of Kamchatka in Holocene, Bulletin of Kamchatka Regional Association "Educational-scientific Center", Earth Sci., 1, 117-144, 2010.

Pevzner, M. M.: Holocene volcanism of the Sredinny Range of Kamchatka, GEOS, Moscow, 2015.

Pevzner, M. M., Ponomareva, V. V., and Melekestsev, I. V.: Chernyi Yar - reference section of the Holocene ash markers at the northeastern coast of Kamchatka, Volcanol. Seismol., 19, 389-406, 1998.

Pevzner, M. M., Ponomareva, V. V., and Sulerzhitsky, L. D.: Holocene soil-pyroclastic covers in the Central Kamchatka depression: age, structure, specifics of sedimentation, Volcanol. Seismol., 1, 24-38, 2006 (in Russian).

Pinegina, T. K., Kozhurin, A. I., and Ponomareva, V. V.: Seismic and tsunami hazard for Ust'-Kamchatsk village, Kamchatka, based on paleoseismological data,Bulletin of Kamchatka Regional Association "Educational-scientific Center", Earth Sci., 1, 138-159, 2012 (in Russian).

Pinegina, T. K., Bourgeois, J., Kravchunovskaya, E. A., Lander, A. V., Arcos, M. E., Pedoja, K., and MacInnes, B. T.: A nexus of plate interaction: Vertical deformation of Holocene wavebuilt terraces on the Kamchatsky Peninsula (Kamchatka, Russia), Geol. Soc. Am. Bull., 125, 1554-1568, 2013.

Pinegina, T. K., Kozhurin, A. I., and Ponomareva, V. V.: Active tectonics and geomorphology of the Kamchatsky Bay coast in Kamchatka, Russ. J. Pac. Geol., 8, 65-76, 2014.

Plank, T.: Constraints from Thorium/Lanthanum on Sediment Recycling at Subduction Zones and the Evolution of the Continents, J. Petrol., 46, 921-944, 2005.

Plechova, A. A., Portnyagin, M. V., and Bazanova, L. I.: The Origin and Evolution of the Parental Magmas of Frontal Volcanoes in Kamchatka: Evidence from Magmatic Inclusions in Olivine from Zhupanovsky Volcano, Geochem. Int., 49, 743768, https://doi.org/10.1134/S0016702911080064, 2011.

Plunkett, G., Coulter, S. E., Ponomareva, V. V., Blaauw, M., Klimaschewski, A., and Hammarlund, D.: Distal tephrochronology in volcanic regions: Challenges and insights from Kamchatkan lake sediments, Global Planet. Chang., 134, 26-40, 2015.

Ponomareva, V., Portnyagin, M., Derkachev, A., Juschus, O., Garbe-Schönberg, D., and Nürnberg, D.: Identification of a widespread Kamchatkan tephra: a mid-Pleistocene tie-point between Arctic and Pacific paleoclimatic records, Geophys. Res. Lett., 40, 3538-3543, https://doi.org/10.1002/grl.50645, $2013 \mathrm{a}$.

Ponomareva, V., Portnyagin, M., Derkachev, A., Pandea, I. F., Bourgeois, J., Krasheninnikov, S., Garbe-Schönberg, D., and Nürnberg, D.: Early Holocene M 6 explosive eruption from Ushkovsky volcano (Kamchatka) and its tephra as a link between terrestrial and marine paleoenvironmental records, Int. J. Earth Sci., 102, 1673-1699, https://doi.org/10.1007/s00531-013-0898$0,2013 b$.
Ponomareva, V., Portnyagin, M., and Davies, S.: Tephra without borders: Far-reaching clues into past explosive eruptions, Front. Earth Sci., 3, p. 83, https://doi.org/10.3389/feart.2015.00083, 2015a.

Ponomareva, V., Portnyagin, M., Pevzner, M., Blaauw, M., Kyle, P., and Derkachev, A.: Tephra from andesitic Shiveluch volcano, Kamchatka, NW Pacific: chronology of explosive eruptions and geochemical fingerprinting of volcanic glass, Int. J. Earth Sci., 104, 1459-1482, 2015b.

Ponomareva, V., Portnyagin, M., Pendea, I. F., Zelenin, E., Bourgeois, J., Pinegina, T., and Kozhurin, A.: A full Holocene tephrochronology for the Kamchatsky Peninsula region: applications from Kamchatka to North America, Quaternary Sci. Rev., 168, 101-122, https://doi.org/10.1016/j.quascirev.2017.04.031, 2017.

Ponomareva, V., Bubenshchikova, N., Portnyagin, M., Zelenin, E., Derkachev, A., Gorbarenko, S., Garbe-Schönberg, D., and Bindeman, I.: Large-magnitude Pauzhetka caldera-forming eruption in Kamchatka: Astrochronologic age, composition and tephra dispersal, J. Volcanol. Geoth. Res., 366, 1-12, https://doi.org/10.1016/j.jvolgeores.2018.10.006, 2018.

Ponomareva, V. V.: The history of Krasheninnikov volcano and the dynamics of its activity, Volcanol. Seismol., 9, 714-741, 1990.

Ponomareva, V. V., Melekestsev, I. V., and Dirksen, O. V.: Sector collapses and large landslides on Late Pleistocene-Holocene volcanoes in Kamchatka, Russia, J. Volcanol. Geoth. Res., 158, 117-138, 2006.

Portnyagin, M. V., Ponomareva, V. V., Zelenin, E. A., Bazanova, L. I., Pevzner, M. M., Plechova, A. A., Rogozin, A. N., and Garbe-Schönberg, D.: TephraKam: Geochemical database of glass compositions in tephra and welded tuffs from the Kamchatka volcanic arc (NW Pacific), Data files, https://doi.org/10.13140/RG.2.2.23627.13606, 2019.

Rasmussen, S. O., Andersen, K. K., Svensson, A., Steffensen, J. P., Vinther, B. M., Clausen, H. B., Siggaard-Andersen, M. L., Johnsen, S. J., Larsen, L. B., and Dahl-Jensen, D.: A new Greenland ice core chronology for the last glacial termination, J. Geophys. Res.-Atmos., 111, D06102, https://doi.org/10.1029/2005JD006079, 2006.

Reimer, P. J., Bard, E., Bayliss, A., Beck, J. W., Blackwell, P. G., Ramsey, C. B., Buck, C. E., Cheng, H., Edwards, R. L., and Friedrich, M.: IntCal13 and Marine13 radiocarbon age calibration curves 0-50,000 years cal BP, Radiocarbon, 55, 1869-1887, https://doi.org/10.2458/azu_js_rc.55.16947, 2013.

Schattel, N., Portnyagin, M., Golowin, R., Hoernle, K., and Bindeman, I.: Contrasting conditions of rift and off-rift silicic magma origin on Iceland, Geophys. Res. Lett., 41, 5813-5820, 2014.

Seligman, A., Bindeman, I., Jicha, B., Ellis, B., Ponomareva, V., and Leonov, V.: Multi-Cyclic and Isotopically Diverse Silicic Magma Generation in an Arc Volcano: Gorely Eruptive Center, Kamchatka, Russia, J. Petrol., 55, 1561-1594, https://doi.org/10.1093/petrology/egu034, 2014.

Smith, W. H. F. and Sandwell, D. T.: Global seafloor topography from satellite altimetry and ship depth soundings, Science, 277, 1956-1962, 1997.

Straub, S. M., Layne, G. D., Schmidt, A., and Langmuir, C. H.: Volcanic glasses at the Izu arc volcanic front: New perspectives on fluid and sediment melt recycling in 
subduction zones, Geochem. Geophy. Geosy., 5, Q01007, https://doi.org/10.1029/2002GC000408, 2004.

Straub, S. M., Woodhead, J. D., and Arculus, R. J.: Temporal Evolution of the Mariana Arc: Mantle Wedge and Subducted Slab Controls Revealed with a Tephra Perspective, J. Petrol., 56, 409439, 2015.

Tomlinson, E. L., Thordarson, T., Müller, W., Thirlwall, M., and Menzies, M. A.: Microanalysis of tephra by LA-ICPMS - Strategies, advantages and limitations assessed using the Thorsmörk ignimbrite (Southern Iceland), Chem. Geol., 279, 73 89, 2010.

Turney, C. S., Lowe, J. J., Davies, S. M., Hall, V., Lowe, D. J., Wastegård, S., Hoek, W. Z., and Alloway, B.: Tephrochronology of Last Termination sequences in Europe: a protocol for improved analytical precision and robust correlation procedures (a joint SCOTAV-INTIMATE proposal), J. Quaternary Sci., 19, 111-120, 2004.

van der Bilt, W. G., Lane, C. S., and Bakke, J.: Ultra-distal Kamchatkan ash on Arctic Svalbard: towards hemispheric cryptotephra correlation, Quaternary Sci. Rev., 164, 230-235, https://doi.org/10.1016/j.quascirev.2017.04.007, 2017.

Vinther, B. M., Clausen, H. B., Johnsen, S. J., Rasmussen, S. O., Andersen, K. K., Buchardt, S. L., Dahl-Jensen, D., Seierstad, I. K., Siggaard-Andersen, M. L., and Steffensen, J. P.: A synchronized dating of three Greenland ice cores throughout the Holocene, J. Geophys. Res.-Atmos., 111, D13102, https://doi.org/10.1029/2005JD006921, 2006.
Volynets, O. N.: Geochemical types, petrology, and genesis of the late Cenozoic volcanic rocks from the Kurile-Kamchatka islandarc system, Int. Geol. Rev., 36, 373-403, 1994.

Volynets, O. N., Melekestsev, I. V., Ponomareva, V. V., and Yogodzinski, J. M.: Kharchinskii and Zarechnyi volcanoes, unique centers of Late Pleistocene magnesian basalts in Kamchatka: tectonic setting, morphology, age and geologic structure, Vulkanologiya i Seismologiya, 4-5, 5-18, 1998 (in Russian).

Westgate, J., Perkins, W., Fuge, R., Pearce, N., and Wintle, A.: Trace-element analysis of volcanic glass shards by laser ablation inductively coupled plasma mass spectrometry: application to tephrochronological studies, Appl. Geochem., 9, 323-335, 1994.

Zaretskaia, N. E., Ponomareva, V. V., Sulerzhitsky, L. D., and Dirksen, O. V.: Radiocarbon dating of the Kurile Lake Caldera eruption (South Kamchatka, Russia), Geochronometria, 20, 95-102, 2001.

Zaretskaya, N. E., Ponomareva, V. V., and Sulerzhitsky, L. D.: Radiocarbon dating of large Holocene volcanic events within South Kamchatka (Russian Far East), Radiocarbon, 49, 1065-1078, 2007.

Zelenin, E., Kozhurin, A., Ponomareva, V., and Portnyagin, M.: Tephrochronological dating of paleoearthquakes in active volcanic arcs: A case of the Eastern Volcanic Front on the Kamchatka Peninsula (NW Pacific), J. Quaternary Sci., 35, 349-361, https://doi.org/10.1002/jqs.3145, 2020. 